\title{
Great Britain: The Intertidal and Underwater Archaeology of Britain's Submerged Landscapes
}

\author{
Geoff Bailey, Garry Momber, Martin Bell, \\ Louise Tizzard, Karen Hardy, Andrew Bicket, \\ Lauren Tidbury, Jonathan Benjamin, \\ and Alex Hale
}

\section{Abstract}

The submerged landscapes around Great Britain are extensive and would have offered productive territory for hunting, gathering,

G. Bailey $(\bowtie)$

Department of Archaeology, University of York, York, UK

College of Humanities, Arts and Social Sciences, Flinders University, Adelaide, SA, Australia e-mail: geoff.bailey@york.ac.uk

G. Momber

Maritime Archaeology Trust, National Oceanography

Centre, Southampton, UK

Department of Archaeology, University of York, York, UK

e-mail: garry.momber@maritimearchaeologytrust.org

M. Bell

Department of Archaeology, School of Human and Environmental Sciences, University of Reading,

Reading, UK

e-mail:m.g.bell@reading.ac.uk

L. Tizzard

Wessex Archaeology, Portway House,

Salisbury, Wiltshire, UK

e-mail: 1.tizzard@wessexarch.co.uk

K. Hardy

Department of Archaeology, University of York,

York, UK

ICREA, Barcelona, Catalonia, Spain

Departament de Prehistòria, Facultat de Filosofia i

Lletres, Universitat Autònoma de Barcelona,

Barcelona, Catalonia, Spain

e-mail: karhardy@icrea.cat exploitation of aquatic and marine resources, and-in the final stages of postglacial sealevel rise-opportunities for agriculture. They would also have provided land connections to continental Europe and opportunities for communication by sea travel along now-submerged palaeocoastlines and river estuaries. Most of the archaeological material has been discovered in intertidal or shallow water conditions, but there are also discoveries in deeper water, with dates ranging from earliest human presence nearly one million years ago up to the establishment of modern sea level. Some later material is present where coastlines have continued to sink in more recent millennia. Intertidal sites are especially well represented

\footnotetext{
A. Bicket

Wessex Archaeology, Edinburgh, UK

Department of Geography, Loughborough University, Loughborough, UK

e-mail: a.bicket@wessexarch.co.uk

L. Tidbury

Museum of London Archaeology, Mortimer Wheeler House, London, UK

e-mail: LTidbury@ mola.org.uk

J. Benjamin

College of Humanities, Arts and Social Sciences,

Flinders University, Adelaide, SA, Australia

e-mail: Jonathan.benjamin@flinders.edu.au

A. Hale

Historic Environment Scotland, John Sinclair House, Edinburgh, UK

e-mail: alex.hale@hes.scot
} 
because of relatively large tidal ranges and shallow offshore gradients on many coastlines. These are often associated with remains of submerged forests, which are periodically exposed at low tide and then covered up again by movements of sand. Some of the most distinctive intertidal finds are the human and animal footprints preserved in intertidal sediments in many locations, especially at Goldcliff East. The earliest, at Happisburgh, are dated between 0.78 and 1 Ma. Fully submerged sites include the Mesolithic site of Bouldnor Cliff with its worked timbers, and the Middle Stone Age artefacts from offshore aggregate Area 240 along with well-preserved ice age fauna and environmental indicators. Pioneering work using oil industry seismic records has produced detailed reconstructions of the submerged landscape, and this is being followed up by new work involving targeted acoustic survey and coring of sediments.

\section{Keywords}

Submerged forests - Intertidal · Happisburgh · Bouldnor Cliff · Goldcliff East · Area A240

\subsection{Introduction}

This chapter concerns Great Britain, a geographical term for the largest island of the British Isles, which includes England, Wales and Scotland, their territorial waters and offshore islands such as the Isle of Wight, the Hebrides, the Orkney Islands and the Shetland Islands (Fig. 10.1). The island of Ireland includes the Republic of Ireland and Northern Ireland (which is politically a part of the United Kingdom), and is treated separately (Westley and Woodman, Chap. 11, this volume). ${ }^{1}$

\footnotetext{
${ }^{1}$ The United Kingdom is a political unit comprising England and the devolved administrations of Scotland, Wales and Northern Ireland (the latter suspended at the time of writing). The British Isles, or the British and Irish Isles, refer to a geographical entity that comprises the islands of Great Britain and Ireland. The Isle of Man and the Channel Islands (principally Guernsey and Jersey) are Crown Dependencies, self-governing administrations out-
}

We summarise the geological and environmental changes of the Quaternary period of relevance to archaeological interpretation of Great Britain's submerged landscapes with reference to the more detailed information in Flemming et al. (2017) and provide an overview of the intertidal and underwater archaeological material and the conditions that have contributed to its preservation and discovery, followed by a more detailed description of individual finds. In a concluding assessment, we consider the wider significance of what is already known and some directions for future research.

\subsection{The Geological and Palaeogeographical Context}

Great Britain has numerous peninsulas, smaller offshore islands and archipelagos, a long coastline relative to its land area (some $17,800 \mathrm{~km}$ of coastline relative to an area of $209,000 \mathrm{~km}^{2}$ ) and is surrounded by extensive areas of nowsubmerged landscape (Bicket and Tizzard 2015; Westley 2017; Cohen et al. 2017; Farr et al. 2017). The central and southern sectors of the North Sea Basin formed the principal area of lowland territory on the exposed continental shelf, and this area has come to be known as Doggerland, after the Dogger Bank, which would have formed a low rise on the coastal plain (Coles 1998; Fig. 10.2). ${ }^{2}$ At its maximum extent, the

side the United Kingdom but for which the UK government takes responsibility particularly in international affairs. For convenience, we include here brief reference to archaeological evidence on Jersey, though the island is geographically closer to France than to England (see Billard et al., Chap. 12, this volume). Evidence from Gibraltar, which is a British Overseas Territory, is discussed with evidence from Spain by Arias in Chap. 13, this volume.

${ }^{2}$ Note that the area of exposed land in the North Sea at low sea level partly falls within the Exclusive Economic Zones of Norway, Denmark, Germany, the Netherlands, Belgium and France, as well as the United Kingdom, see Fig. 1.1, this volume, and references to underwater investigations of Doggerland occur in the relevant national chapters in this volume. 


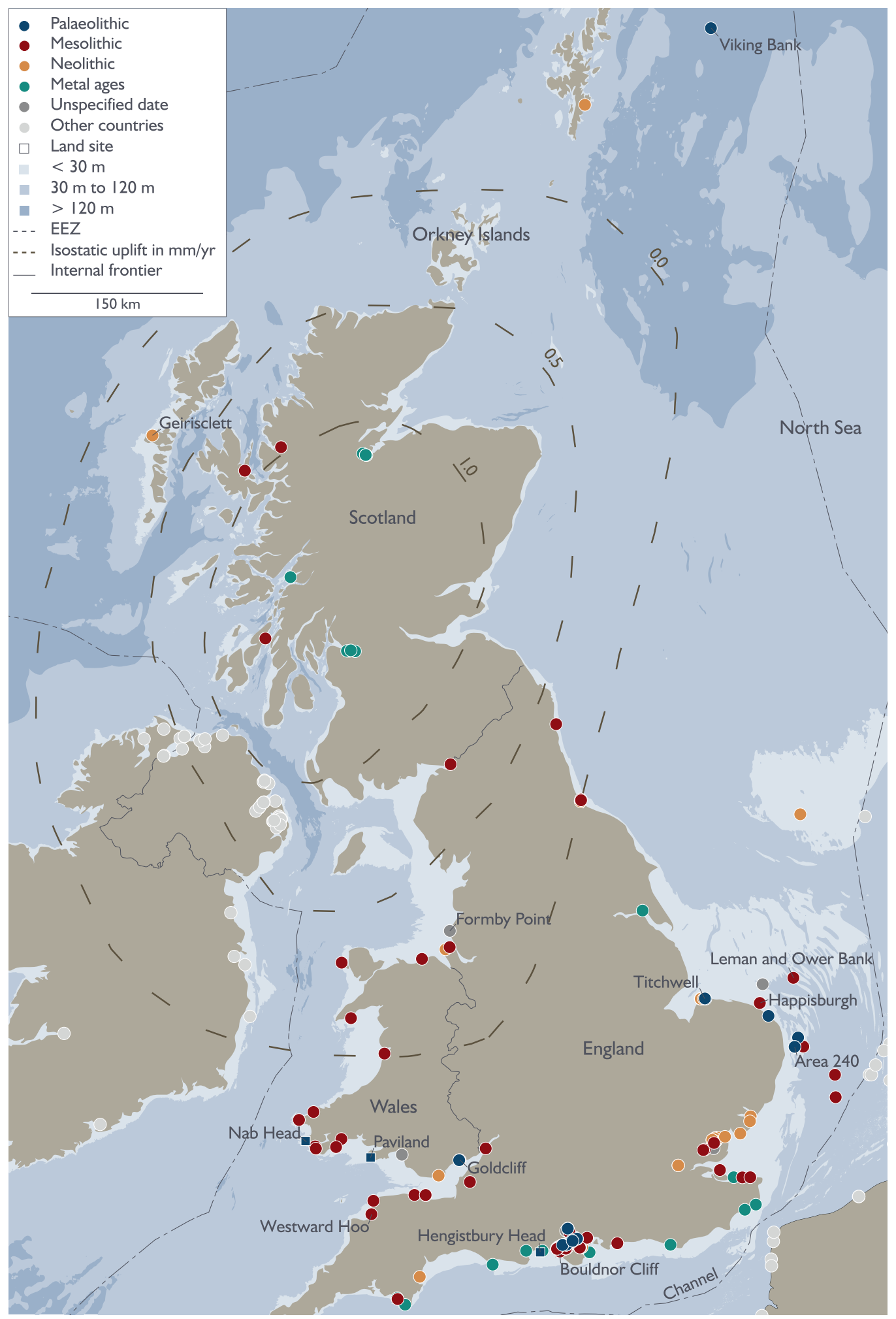

Fig. 10.1 Map showing the location of underwater finds with names of sites and geographical areas mentioned in the text. Within the dotted lines to the North the Earth's crust is rising, while south of it the land has been slightly subsiding since the Stone Age. Site information from the SPLASHCOS Viewer http://splashcos-viewer.eu. Drawing by Moritz Mennenga 


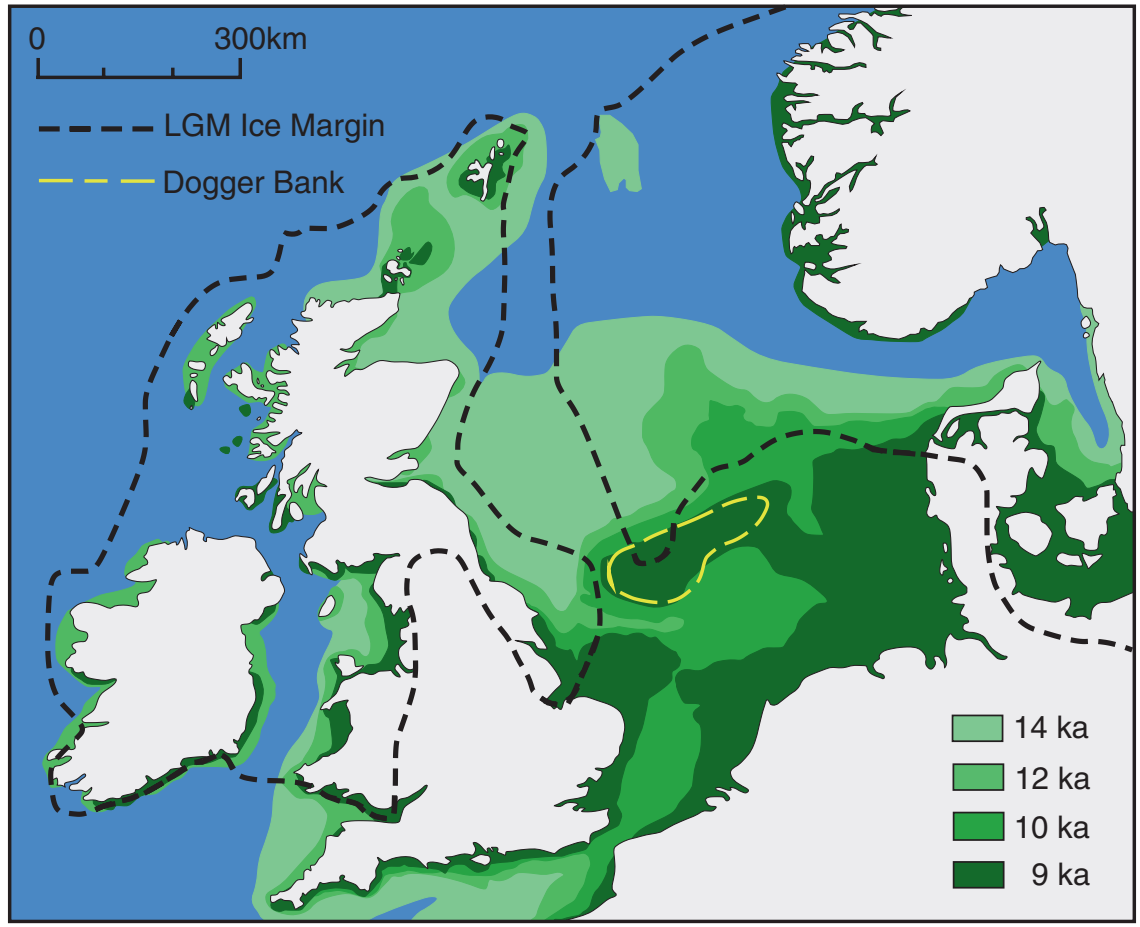

Fig. 10.2 Map demonstrating the extent of land exposed at successive stages during the progressive rise of sea level after the Last Glacial Maximum (LGM). Additional areas of land would have been exposed at the height of the LGM when sea level was at its lowest, but these areas would have been uninhabitable or inaccessible because of proximity to the ice sheets, except to the south-west of the English mainland. Also shown is the area of the Dogger Bank, which would have been exposed as a low hill in a broad coastal plain until late in the process of sea-level rise. Recovery in a fishing net of an Early Mesolithic antler artefact at the eastern end of the Dogger Bank in Danish territorial waters demonstrates that the area was visited when it was still dry land (see Bailey et al., Chap. 3, this volume, Fig. 3.4). Neolithic axes of a later date are discussed in the text. Data from Shennan and Andrews (2000); Shennan et al. (2006); Sturt et al. (2013) and Harff et al. (2017). Dates are calibrated radiocarbon years, but note that dates and coastlines are approximate and based on model predictions only weakly constrained by dated palaeoshorelines features. Lambeck, in Harff et al. (2017, Figure 2.13) gives slightly earlier dates for the separation of Doggerland. Drawing by Geoff Bailey

amount of new land exposed on the continental shelf around Great Britain would have been at least as extensive as the present-day land surface and is likely to have played a particularly significant role in the early history of human occupation. It would have provided a major pathway of contact and migration between Britain and mainland Europe and an extensive territory of coastal plains, low hills, rivers, lakes and marshlands well stocked with large mammals, plant life, fish and wildfowl, marine resources at the shore edge, and opportunities for sea travel along its nowsubmerged shorelines. Stone Age coastlines and coastal hinterlands should, therefore, be well represented in the underwater archaeological record.
At the same time, the extent and configuration of these submerged territories and the nature of the connection between Britain and the European continent have been subject to highly variable and dynamic palaeogeographical and palaeoenvironmental changes in response to a complex interplay of climatic and geological processes. These include variations in sea level resulting from changes in ice volume (global eustasy), hydro-isostatic and glacio-isostatic changes associated with the glacial-interglacial cycle, which caused episodic subsidence and rebound of the Earth's crust at a regional scale because of the loading and unloading of continental ice sheets, and of water masses in shallow basins, and slow 
tectonic subsidence of the southern North Sea basin (Westley 2017). These processes have had a major impact not only on the changing configuration of lowland territory, coastlines and land accessible to human settlement, but also on the conditions for the preservation and exposure of submerged landscapes and their associated archaeology.

In the earlier part of the Pleistocene, there was a permanent land connection between Britain and the European mainland across what is now the Dover Strait, and accumulation around the coastal rim of the palaeo-North-Sea of thick fluvial and deltaic sediments that are now submerged. At some time after about half a million years ago, when glacial meltwaters finally broke the land connection between Britain and Europe, Great Britain became isolated from the European mainland during subsequent high sea-level episodes, and access by land was only possible during periods of lower sea level, though not during the glacial maxima, when blanket cover of ice sheets would have deterred settlement (Cohen et al. 2017; Dawson et al. 2017; Farr et al. 2017).

\subsection{The Archaeological Context: Submerged Coasts and Marine Resources}

The earliest occupation of Britain extends back to nearly one million years (Parfitt et al. 2010), and even from this earliest period coastal areas were clearly an attraction to human populations, including landscapes that are now submerged. Direct evidence for the use of marine resources is absent but some of the earliest sites were certainly very close to their contemporaneous shorelines, notably the group of early sites in SE England: Happisburgh, dated at c. 850,000 years ago and discussed below; the 480,000-year-old site of Boxgrove, where large mammals were trapped and butchered on a coastal plain locally confined by a line of cliffs (Roberts and Parfitt 1999; Pope 2003); and Clacton on the east coast, where the tip of a 400,000 year-old wooden spear was found in fluvial peat deposits exposed by erosion on the foreshore (Allington-Jones 2015).
Numerous isolated finds of Lower Palaeolithic handaxes in southern England have also been reported in the National Monuments Record (https://www.pastscape.org.uk/default.aspx, accessed 2018). These have been found on modern beaches where they are clearly eroded from the adjacent coastal cliffs or dredged up from marine sediments in river estuaries.

At the coastal cave of La Cotte de St Brelade on the island of Jersey, occupied periodically from about 238,000 years ago onwards, the remains of butchered mammoths and other large mammals were recovered (see also Billard et al., Chap. 12, this volume, for further information on this region). The La Cotte faunal remains were originally interpreted as the result of hunters driving the large mammals over the cliff edge from above the site, although the possibility of an extensive coastal plain in front of the site was envisaged at lower sea levels with the use of the ravines at the foot of the cliff for trapping animals (Callow 1986; Scott 1986). Recently, more detailed analysis of the submerged landscape has reinforced the significance of the extensive and now-submerged coastal plain as a habitat for large mammals and has identified a dissected geology of ravines and ridges on its inner margin that would have enabled Neanderthal hunters to use the complex topography to engage in ambushhunting close to the cave (Scott et al. 2014).

Towards the Last Glacial Maximum, when much of northern Britain was covered by ice and the sea was approaching its lowest, the burial of the 'Red Lady' of Paviland in south Wales dated to c. 34,000 cal BP (Jacobi and Higham 2008) close to the southern margin of the ice sheet demonstrates that people were clearly visiting the seashore some distance away to collect marine shells for ornaments. Stable isotope signatures from the human bone remains show that they were also eating marine foods (Richards 2000).

During the Last Glacial Maximum, the British mainland was abandoned, but as the ice retreated, sites linked to late Upper Palaeolithic cultures on the European continent began to appear between about 16,000 and 12,500 years ago. In England, sites are closely linked with the Magdalenian and Federmesser industries of northern France and 
the Low Countries (Momber and Peeters 2017). To the north, in Scotland, a Hamburgian presence is confirmed at Howburn in the Clyde Valley (Ballin et al. 2010, 2018) while finds of stone artefacts elsewhere in Scotland show typological affinities with other northern European industries such as the Ahrensburgian and the Federmesser (Saville and Ballin 2009; Mithen et al. 2015; Ballin 2017, 2019). Most likely, these British Late-Glacial occurrences were outlying upland camps of hunting territories centred on the submerged plains of the North Sea Basin and the English Channel, as Fischer (2004, p. 35) has surmised for the Hamburgian reindeer-hunting sites of NW Germany. Some are in coastal or near-coastal locations, raising the possibility of an early maritime adaptation and a coastal colonisation of northern Britain from the nowsubmerged coasts of Doggerland.

Similarly, the late Upper Palaeolithic site of Hengistbury Head on the English south coast, dated at c. 12,500 years ago (Barton 1992), and the early Mesolithic site of Nab Head in Wales, dated at c. 9500 years ago (Tolan-Smith 2008), are located on the present-day coastline and clearly commanded excellent views over lowlying coastal areas and shorelines, and access to their varied resources, all of which are now submerged. Neither site, however, has direct evidence of marine food remains, perhaps because of distance from the contemporaneous shoreline.

Coastal sites with evidence of marine exploitation located above modern sea level on the modern coastline, such as the shell middens of Oronsay in the Western Isles of Scotland (Mellars 1987), are present towards the end of the Mesolithic period after the establishment of modern sea level at about its present position c. 6000 cal BP (Tolan-Smith 2008), and somewhat earlier at about $10,000 \mathrm{cal} \mathrm{BP}$ on some of the uplifted coastlines of northern Britain at sites such as Howick (Waddington 2007).

All of this indicates that coastal environments close to the contemporaneous shoreline were a prime attraction to the early inhabitants of Great Britain throughout its 1-million-year sequence, with or without the addition of marine resources. Underwater finds are therefore likely to be of great significance in filling some very large gaps in the Stone Age record, and an increasing number of finds have come to light in the past two decades (Fig. 10.1).

\subsection{Conditions of Preservation and Discovery}

Two different sets of factors have influenced the current state of knowledge. The first is the variable geomorphological conditions in which material is likely to have been preserved after inundation by sea-level rise and made visible and accessible to observation. The second refers to the nature of the explorations and underwater activities that have resulted in archaeological discoveries, including the impact of offshore industries.

\subsubsection{Geomorphology}

There is extensive discussion in the recent literature about the potential effects of offshore processes of erosion and sedimentation on the seabed and likely targets for preservation of underwater archaeological deposits around the British Isles (summarised in Flemming et al. 2017). For the present purposes in relation to currently known archaeological discoveries, two general features are of particular relevance: the nature of the intertidal zone; and the effects of tectonic uplift and subsidence.

\subsubsection{The Intertidal Zone}

Because of irregular coastlines, interconnected sea basins and variable seabed bathymetry, the tidal range around the British coast is one of the most variable in Europe and includes some of the highest tidal ranges in the world. Mean springtidal range varies from less than $2 \mathrm{~m}$ on the English south coast to $14 \mathrm{~m}$ in the Severn Estuary (Westley 2017). In general, tidal ranges are highest on parts of the west coast of England, lowest on the south coast of England and the south-west coasts of Scotland, and intermediate elsewhere. When combined with shallow offshore gradients, 
large tidal ranges can expose very extensive intertidal mudflats at low tide extending for many hundreds of metres out from the modern shoreline. Moreover, the generally gentle watercurrents in these shallow areas combined with rapid accumulation of sediments, especially at the mouths of river estuaries, means that archaeological material deposited on land and subsequently inundated by sea-level rise is exposed to minimal disturbance before being covered by protective layers of peat or marine sediment.

\subsubsection{Submerged Forests}

One of the distinctive features of the British coastline, which can be observed on many beaches, both on the open coastline and in more sheltered bays and estuaries, is patches of submerged forest exposed at low tide-a variable mixture of tree stumps, fallen tree trunks and peat sediments (Fulford et al. 1997). Even on more exposed beaches, these old land surfaces can be protected for decades or centuries by accumulations of sand and remain invisible until exposed by storm action and the removal of the overlying sediments. Once they are uncovered, further erosion by waves and marine currents may expose the underlying land surface and reveal archaeological features previously sealed beneath the overlying peat. These submerged forests have been the object of scientific enquiry for over a hundred years (see Reid 1913) and the more extensive deposits have been the focus in recent decades of major research investigations into sealevel change and wetlands archaeology.

These intertidal zones have the advantage that they are easily accessible and can be inspected on foot and followed downslope at extreme low tides and even excavated without the need to go underwater, although the window of opportunity for such investigations may be as little as $1 \mathrm{~h}$ in the tidal cycle, and even then, only once every few months for deposits at extreme low water. For the same reason, of course, intertidal deposits are also vulnerable to the destructive effects of human activity along the shoreline including the impact of tourism, construction of roads, buildings and seashore defences, and a variety of recreational, commercial and industrial activities.
Many of the features recorded earlier in the last century have disappeared or been destroyed. They are an object lesson in the delicate balance between burial under protective sediments and exposure by erosion that determines the preservation and visibility of so much of the underwater record. They also testify to the surprising richness of a zone that is all too easily assumed to have little surviving prehistoric archaeology because of the supposedly destructive impacts of shallow-water currents and waves in the surf zone. It is no surprise that the majority of the prehistoric underwater finds known from Britain occur in the intertidal zone, or that they include important finds such as wooden artefacts, dugout canoes, wooden structures, and traces of in situ cultural features and activity areas.

\subsubsection{Uplift and Subsidence}

The major process is land uplift in the North (Fig. 10.1) resulting from isostatic adjustment after the melting of the North European ice sheets of the Last Glacial (see also Jöns et al. Chap. 5, and Glorstad et al. Chap. 6, this volume, for discussion of this process). This uplift has been especially marked in parts of central Scotland. Here large areas of the mainland were depressed under the weight of the overlying ice sheet with a corresponding and compensating uplift-the forebulge-around the edge of the ice sheet. Once the ice melted, the land beneath it rebounded and the forebulge subsided. These processes proceeded at different rates and were further compounded by the hydrostatic effects of rising sea level on shallow shelf areas (Dawson et al. 2017). Because of these complex and regionally variable patterns of coastal uplift and subsidence and their interactions with eustatic sea-level rise, some parts of the Scottish coastline have been uplifted exposing Late Glacial and early postglacial shorelines that would otherwise have been submerged by sea-level rise (sometimes followed by renewed submergence), while in other areas, notably around the Outer Hebrides and the Orkney Islands, the land has been sinking, submerging shorelines and coastal landscapes as late in date as 4000 years ago (Fig. 10.3; Dawson et al. 2017). 


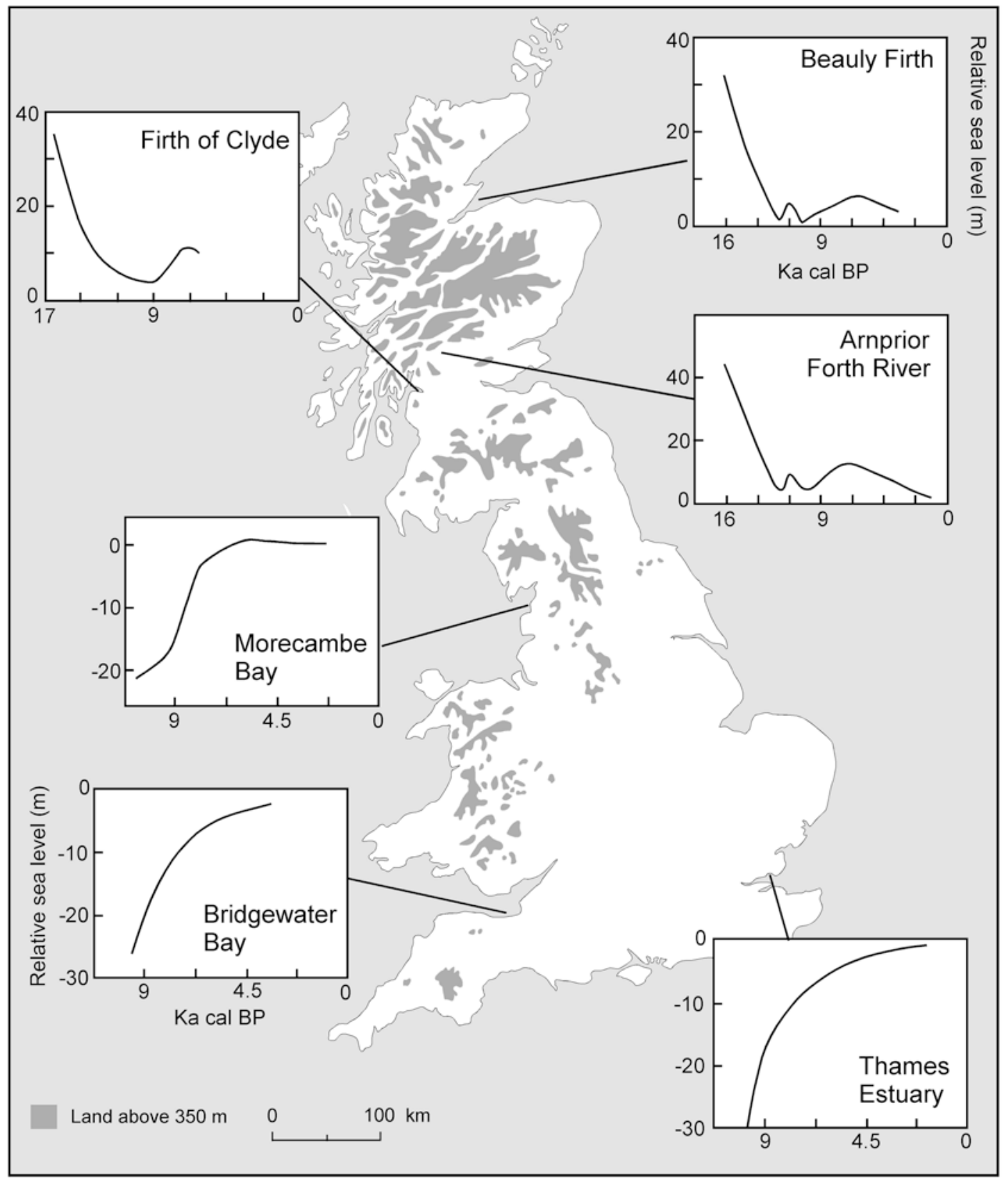

Fig. 10.3 Changes in Late Glacial and Postglacial relative sea level at selected sites in Britain. Sites in the south show a steady rise in sea level following the typical eustatic pattern, whereas the sites in Scotland show a drop in sea-level because isostatic rebound following deglaciation initially outpaced increase in ocean volume. Date scale is in calibrated radiocarbon years, and relative sea level is in metres above or below present sea level. Sea-level data modified from Lambeck (1995). Drawing by Geoff Bailey

The result is that coastal sites of relatively early date, dating back to 10,000 years ago or more, are visible on some of the shorelines of northern Britain (Waddington 2007; Hardy and
Wickham-Jones 2009; Mithen et al. 2015; Momber and Peeters 2017). The converse is also the case, that sites of Neolithic date or later may now be submerged, for example around the 
Orkney islands, with the potential for recovery of well-preserved organic remains in underwater deposits compared to their dryland equivalents in other regions (Bates et al. 2013).

In the south of England, the land is sinking, in part because of adjustment following the melting of the ice sheets, and in part because of tectonic processes operating on a much longer time scale. This has resulted in many drowned river valleys along the present coastline and the accumulation of thick layers of marine sediments that have preserved earlier land surfaces and archaeological finds, but also hidden them from view. Here, discoveries depend on the re-exposure of earlier sediments: by tidal scour and progressive shoreward erosion; by coastal engineering works such as harbour construction, dredging and drilling of boreholes, by fishing activity, and by activation of submarine channels that have cut through overlying marine sediments to expose earlier terrestrial land surfaces.

\subsubsection{Underwater Search and Discovery, and Offshore Industry}

Reporting of material along Britain's shorelines by interested members of the public and more systematic scientific investigations of intertidal material exposed on the foreshore have a long history extending well back into the last century (e.g. Warren et al. 1936). Offshore, the main contributing effect has been the chance recovery of material as a by-product of commercial activities such as trawler fishing, most famously the recovery of a Mesolithic harpoon embedded in a lump of peat recovered by the fishing vessel Colinda in 1932 (Godwin and Godwin 1933).

In the late 1990s, in response to the multiple threats arising from intensified coastal development and the prospect of future climate and sealevel change, a series of reports on the coastal heritage, including underwater finds, were produced to inform Shoreline Management Plans (Fulford et al. 1997; Wessex Archaeology 2007; Hazell 2008; Murphy 2014). These reports incorporate pre-existing data from the National
Monuments Record as well as adding new information.

Offshore, the expansion of industrial exploitation on the seabed in recent decades associated with trawler fishing, oil and gas exploration, sand and aggregate extraction and construction of wind farms has been accompanied by legislation requiring the implementation of archaeological mitigation strategies driven by Environmental Impact Assessments and the need for official marine permits for underwater commercial work (Bicket et al. 2014; Bicket and Tizzard 2015; Sturt et al. 2017; see also Pater, Chap. 26, this volume). Related developments are the existence of a substantial body of existing geological, oceanographic and other marine data that bear indirectly on the archaeological potential of the seabed (Flemming 2004); expansion of specialist underwater units in commercial archaeological companies to service the requirement for Environmental Impact Assessments; a general shift in the intellectual climate of archaeological opinion stimulated by Coles's (1998) paper on Doggerland; and a government tax on offshore and onshore aggregate extraction initiated in 2002. The latter provided substantial funding for archaeological investigations, notably a project that drew on oil company seismic records to reconstruct submerged Stone Age landscapes covering an area of $23,000 \mathrm{~km}^{2}$ in the North Sea (Gaffney et al. 2007, 2009; Fig. 10.4). Since 2005 the British Marine Aggregate Producers Association (BMAPA) has implemented a protocol for ensuring the reporting of underwater archaeological material brought up during commercial activities (Ransley and Sturt 2013).

\subsection{Underwater Finds and the SPLASHCOS Viewer}

\subsubsection{Sources of Information and Criteria for Inclusion}

At the time of writing, the SPLASHCOS viewer contains 258 records of underwater sites or artefacts in Britain, identified mainly from the published literature and from the online data- 


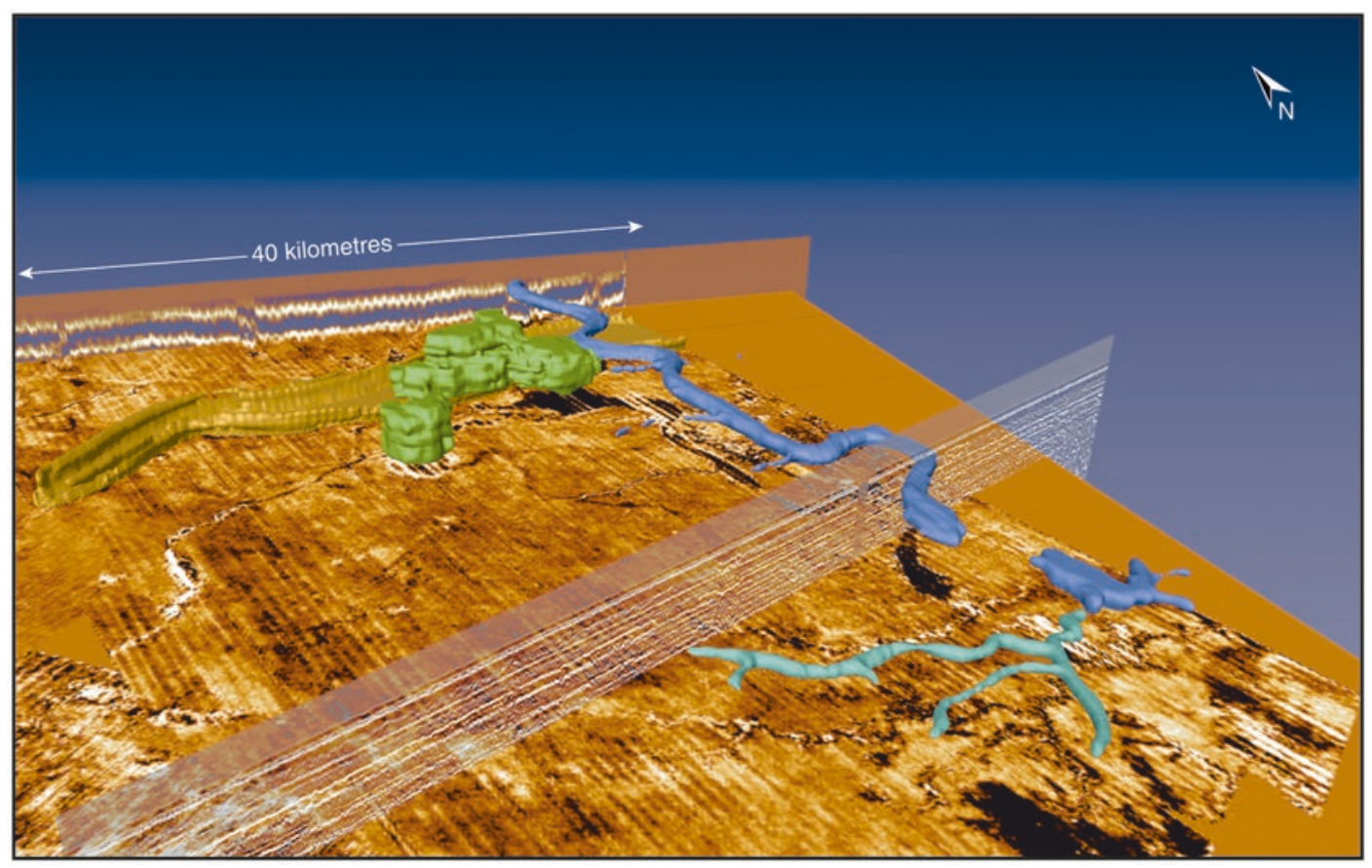

Fig. 10.4 3D reconstruction of an early Holocene meandering river system identified from seismic data beneath the bed of the North Sea. The major channels of the river system are in blue. Green indicates a marshy area. An earlier, Late Glacial, landscape is detectable beneath the Holocene features, and includes a tunnel valley, shown in gold. After Gaffney et al. (2009, figure 5.15), courtesy of Vince Gaffney

bases of archaeological sites maintained by national government agencies and other organisations (Table 10.1).

All these sources have been consulted in compiling the SPLASHCOS record. However, the online sources need to be treated critically. Most include coastal and intertidal finds indiscriminately regardless of whether they are on the landward or the seaward side of the shore margin. Moreover, for intertidal material, the recorded observations rarely pose the question-let alone provide an answer-as to whether the material found has been re-deposited in the intertidal zone because it was eroded out from terrestrial deposits on the landward side of the shore margin, washed up onto the shore from deposits located underwater, or deposited in situ and subsequently exposed by tidal erosion. For our purposes, we include only those sites or archaeological artefacts that were originally deposited on a land surface that was subsequently inundated by relative sea-level rise. Material clearly derived from adja- cent cliffs or land surfaces, or where this cannot be ruled out, have been excluded.

Similarly, numerous individual finds of typologically distinctive stone tools such as Palaeolithic handaxes or Mesolithic tranchet axes have been dredged up over the years from marine sediments in the Thames estuary and other similar contexts where it is likely that the material has been displaced by erosion from the adjacent river bank. These too have been excluded. In cases of ambiguity, we have either excluded the material or relied on descriptions in the published literature. For example, an antler harpoon of Mesolithic type found on the shore at Whitby was examined in detail by Mellars (1970), who concluded from its condition that it had originated from a submerged deposit offshore and not from the adjacent shoreline, and this is included in our list.

If we were to include all the material found in the intertidal zone, our total number of find spots could easily be doubled, but for the reasons outlined above this would be a misleading figure. At 


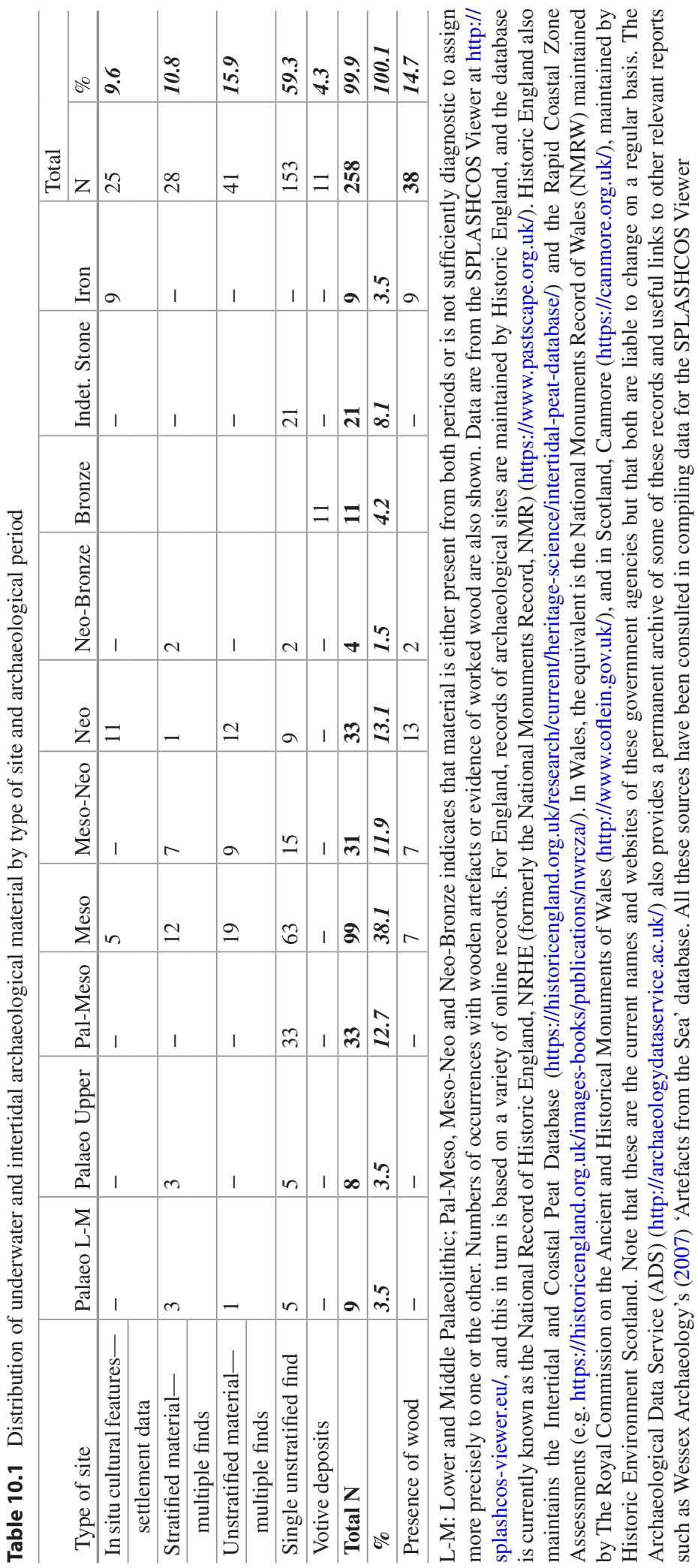


the same time, it is likely that our reduced list is probably a minimum figure. Where intensive investigation has been carried out, for example along the 6-km stretch of shoreline at Wootton Quarr on the north coast of the Isle of Wight, there are multiple occurrences of stone tools, ceramics, wooden trackways and other cultural features, amounting in total to 180 occurrences covering a time range from the late Mesolithic through to the Medieval period (Tomalin et al. 2012). In effect, the shoreline is virtually a single archaeological site forming a spatio-temporal continuum in a wetlands landscape.

The other issue to note is the upper chronological limit for what we include. The primary interest of this volume is, broadly speaking, the period before the establishment of modern sea level at about 6000-5500 years ago. However, some coastlines in Britain, as elsewhere in Europe, have continued to sink, or have been exposed to landward erosion that has resulted in inundation of former land surfaces and their submergence beneath layers of marine sediment. Some of these later sites are relevant to our interests in demonstrating what happens to archaeological settlements and material remains when they are submerged, and we have included some of these examples.

However, deciding where to place the chronological boundary is necessarily somewhat arbitrary. Many of the estuarine mudflats and saltmarshes on the present-day coastline contain more deeply stratified sequences of sub-surface peat or land surfaces with prehistoric archaeological material that fit our criteria. However, many of these coastal zones continued in use into later prehistoric and historical periods right up to the present-day as coastal land surfaces were progressively transformed into freshwater peatlands and saltmarshes. Indeed, these coastal wetlands contain a rich harvest of material culture especially items made of wood including wooden trackways, fish traps, boats, animal byres and other wooden structures, which demonstrates their continuing attractiveness as sources of food, raw materials and seasonal animal grazing at all periods (Bell 2013). Most of these finds, however, refer to the exploitation of coastal wetlands or saltmarshes in approximately their present position in relation to modern sea level, and do not represent underwater finds in the sense used in this volume. Unless they have demonstrably been inundated by sea-level rise or marine sediments after abandonment, we exclude such finds, though we recognise their significance as evidence of wetland exploitation in more recent millennia. Notable examples that we include are the timber henges off the coast of Norfolk (Brennand and Taylor 2003) and the Iron Age marine crannogs of Scotland (Hale 2004), all of which have been partially inundated since they were in use. We have also included a small number of Bronze Age finds, where the range of artefacts present indicates material that has been deliberately deposited offshore and under water as a votive offering (Samson 2006). Such votive deposits are also common in rivers and lakes and it is possible that Neolithic and earlier artefacts, found on the seabed but excluded from our list because of the ambiguity of their provenance, may fall into the votive category, notably the Neolithic polished axes recovered from the Dogger Bank and discussed below.

\subsubsection{Archaeological Overview}

Of our 258 records, $153(59 \%)$ are unstratified single finds, while only 53 records $(20 \%)$ are of multiple finds in stratified context or with in situ cultural features (Table 10.1). In terms of chronology, the material ranges from the Lower Palaeolithic through to the Iron Age. The largest group are Mesolithic finds, comprising 99 records (38\%), followed by finds of Late Palaeolithic and/or Mesolithic date and Mesolithic and/or Neolithic-33 (13\%) and 31 (12\%), respectively. Just five Mesolithic and 11 Neolithic records can be associated with in situ settlement-material, plus the nine Scottish crannogs. However, this may be a considerable underestimate since many finds labelled as 'collective finds of stratified material' may represent in situ cultural features but are too incomplete to judge their context with certainty. Wooden artefacts are preserved at 38 sites (15\%), mostly of Mesolithic or Neolithic 
Table 10.2 Distribution of underwater and intertidal archaeological material by type of site and depth of recovery

\begin{tabular}{|c|c|c|c|c|c|c|c|}
\hline \multirow[b]{2}{*}{ Type of site } & \multicolumn{2}{|c|}{ Intertidal } & \multirow{2}{*}{$\begin{array}{l}\text { Offshore } \\
\leq 12 \mathrm{~m}\end{array}$} & \multirow{2}{*}{$\begin{array}{l}\text { Offshore } \\
18-35 \mathrm{~m}\end{array}$} & \multirow{2}{*}{$\begin{array}{l}\text { Offshore } \\
140-145 \mathrm{~m}\end{array}$} & \multicolumn{2}{|c|}{ Total } \\
\hline & Indet & SF & & & & $\mathrm{N}$ & $\%$ \\
\hline In situ cultural features- & 19 & 8 & 1 & - & - & 28 & 10.9 \\
\hline \multicolumn{8}{|l|}{ settlement data } \\
\hline Stratified material— & 7 & 15 & - & 2 & - & 24 & 9.3 \\
\hline \multicolumn{8}{|l|}{ multiple finds } \\
\hline Stratified material—- & - & - & - & - & 1 & 1 & 0.4 \\
\hline \multicolumn{8}{|l|}{ single find } \\
\hline Unstratified material—- & 3 & 27 & 1 & 1 & - & 32 & 12.4 \\
\hline \multicolumn{8}{|l|}{ multiple finds } \\
\hline Single unstratified find & 87 & 3 & 67 & 5 & - & 162 & 62.8 \\
\hline Votive finds & - & - & 10 & 1 & - & 11 & 4.3 \\
\hline Total & 116 & 53 & 79 & 9 & 1 & 258 & 100.1 \\
\hline$\%$ & 45 & 20.5 & 30.6 & 3.5 & 0.4 & 100 & \\
\hline
\end{tabular}

Intertidal refers to material observed at low tide, offshore to finds recovered by dredging or coring. SF: Submerged forest. Indet: intertidal deposits not certainly associated with submerged forests, may include peat deposits. Data from http://splashcos-viewer.eu/

age. These statistics with their dominance of Mesolithic and Neolithic artefacts reflect the ease of discovery of material that was inundated only towards the end of postglacial sea-level rise and is therefore exposed in the present-day intertidal zone or in shallow water down to depths of about $10 \mathrm{~m}$.

A further breakdown of the records shows that the majority, 169 (66\%), refer to material in the intertidal zone (Table 10.2). In addition, approximately half these intertidal records refer to finds in or beneath submerged forests and this category includes the best preserved of the prehistoric sites including most of the examples of in situ cultural features or settlement data. A further 79 (31\%) refer to underwater finds in a depth range down to about $12 \mathrm{~m}$, with just nine finds (4\%) - though a very important and informative group - in the 18-35 m depth range, and one outlier at 140-145 $\mathrm{m}$, namely the artefact recovered from coring on the Viking-Bergen bank and associated with what are interpreted as beach deposits.

\subsection{Sites in the Intertidal Zone}

Many records in this category are individual artefacts or finds of material for which only fleeting observations were possible at the time of discovery, where questions of artefact descriptions, stratigraphic relationships and chronology remain unresolved. This is especially the case for submerged forests, which were often exposed by storms for a limited period, accessible only at low tide and then covered over again by shifting sediments. Much of the archaeological material is fragmentary, of uncertain provenance or date, or poorly reported. Some records suggest finds of major potential significance which remain tantalising in their incompleteness. Thurlestone Sands near Torbay in south Devon is a good example. Here submerged forests were observed after exposure by a hurricane-force gale in 1866, and again in the same area of the beach after a storm in 1923 (https://www.pastscape.org.uk/hob. aspx?hob_id=441056). The finds reported in 1923 included tree stumps, fallen tree trunks, three of which were recovered from the subsoil beneath the forest layer, a Mesolithic tranchet axe and a perforated mace head. One of the trunks was removed, cleaned and found to have been shaped in the form of a dugout canoe with evidence of tool marks. The find was not conserved and has since been lost.

A similar record comes from Hartlepool Bay, NE England, where submerged peats exposed at various points along the foreshore are reported to have yielded a Neolithic human skeleton, Mesolithic flints, a red deer skeleton with a wooden spear embedded in the rib cage, wooden 
stakes, wattle hurdling and a possible fish weir, with radiocarbon dates indicating a time range of 6000 to $5500 \mathrm{cal} \mathrm{BP}$ for at least part of this material (Trechmann 1936; Buglass 1994; Waugham et al. 2005). Isolated finds of human material have been reported elsewhere including a human skeleton from Liverpool Bay beneath peats radiocarbon-dated between 7500 and 7000 cal BP (Huddart et al. 1999).

An important find at Titchwell on the Norfolk coast is a Late Glacial long-blade industry found in situ on a palaeosol exposed at extreme low water $500 \mathrm{~m}$ offshore from the modern beach. The old land surface had been exposed by erosion of an overlying peat horizon dated at 9000 cal BP (Wymer and Robins 1994). The industry is of Creswellian type, dated by association with finds elsewhere at 13,000 to $12,000 \mathrm{cal}$ BP. Over 600 artefacts were found in situ along with burnt flints, charcoal and three bovid teeth. A nearby channel probably indicates a contemporaneous stream at a time when sea level was some $40 \mathrm{~m}$ below present and the nearest coastline more than $100 \mathrm{~km}$ distant.

Other notable finds are the Mesolithic shell midden stratified beneath a submerged forest and later exposed at low tide at Westward Ho! in SW England (Balaam et al. 1987), and extensive traces of Mesolithic and Neolithic settlements and activity areas with flint tools and wooden artefacts in the Severn Estuary (Bell 2007, and below), at Wootton Quarr on the Isle of Wight (Tomalin et al. 2012), and in the estuaries of the Rivers Thames, Blackwater and Crouch on the Essex coast (Wilkinson and Murphy 1986, 1995; Sidell and Haughey 2007).

On the Essex coast, important Neolithic settlements such as the Stumble and Rolls Farm were occupied when sea level was slightly lower than present and were subsequently inundated and covered by marine sediments and later by coastal peat. As Wilkinson and Murphy (1995, p. x, p. 3) have observed, the original land surface sealed beneath the marine sediment preserves extensive spatial distributions of various features such as pits, postholes and other cultural debris that would have little chance of surviving the effects of plough damage to Neolithic sites further inland, where the material has been reduced to amorphous lithic scatters. On the other hand, wooden artefacts are not preserved at these sites because they were not inundated until sometime after abandonment. Interestingly, the peat deposits that later accumulated above these Neolithic layers do contain organic remains of Bronze Age and later date, but these represent the use of a wetland landscape that was not subsequently inundated by further sea-level rise.

Other late-dated examples are the submerged Bronze Age terrestrial landscape recorded at Langstone Harbour on the south coast with urn burials and burnt mounds (Allen and Gardiner 2000), Early Bronze Age circular wooden henges c. $10 \mathrm{~m}$ in diameter of possible ritual significance at Holme-next-the-Sea on the Norfolk coast (Brennand and Taylor 2003), and Bronze Age barrows and a possible henge on the Humber River in the northeast of England (Van de Noort 2004).

In Scotland, a chambered stone cairn at Geirisclett on the island of North Uist in the North-west has its base at high water mark in the intertidal zone (Benjamin et al. 2014, Fig. 6), and a series of marine crannogs in the Beauly Firth (in the north-east) and the Firth of Clyde (in the south-west) are shoreline settlements that have been inundated by relative sea-level rise (Fig. 10.5; Hale 2004; Jacobsson et al. 2017).

One of the difficulties of systematic work in the intertidal zone is the brief windows of opportunity for detailed work allowed at low tide, and the likelihood of progressive and rapid destruction of what is visible by continued erosion. Nevertheless, important large-scale, multidisciplinary projects have addressed this challenge and generated important results with a wealth of features including numerous remains of wooden artefacts, especially on the Severn Estuary, at Wootton Quarr on the Isle of Wight, and on the Essex Coast, as detailed above. These projects have generally taken a holistic approach to the palaeoenvironmental and archaeological examination of these wetland landscapes through time and across the boundary between dry land, coastal saltmarshes and the intertidal zone, occasionally extending to offshore and underwater investigations as at Wootton Quarr. 


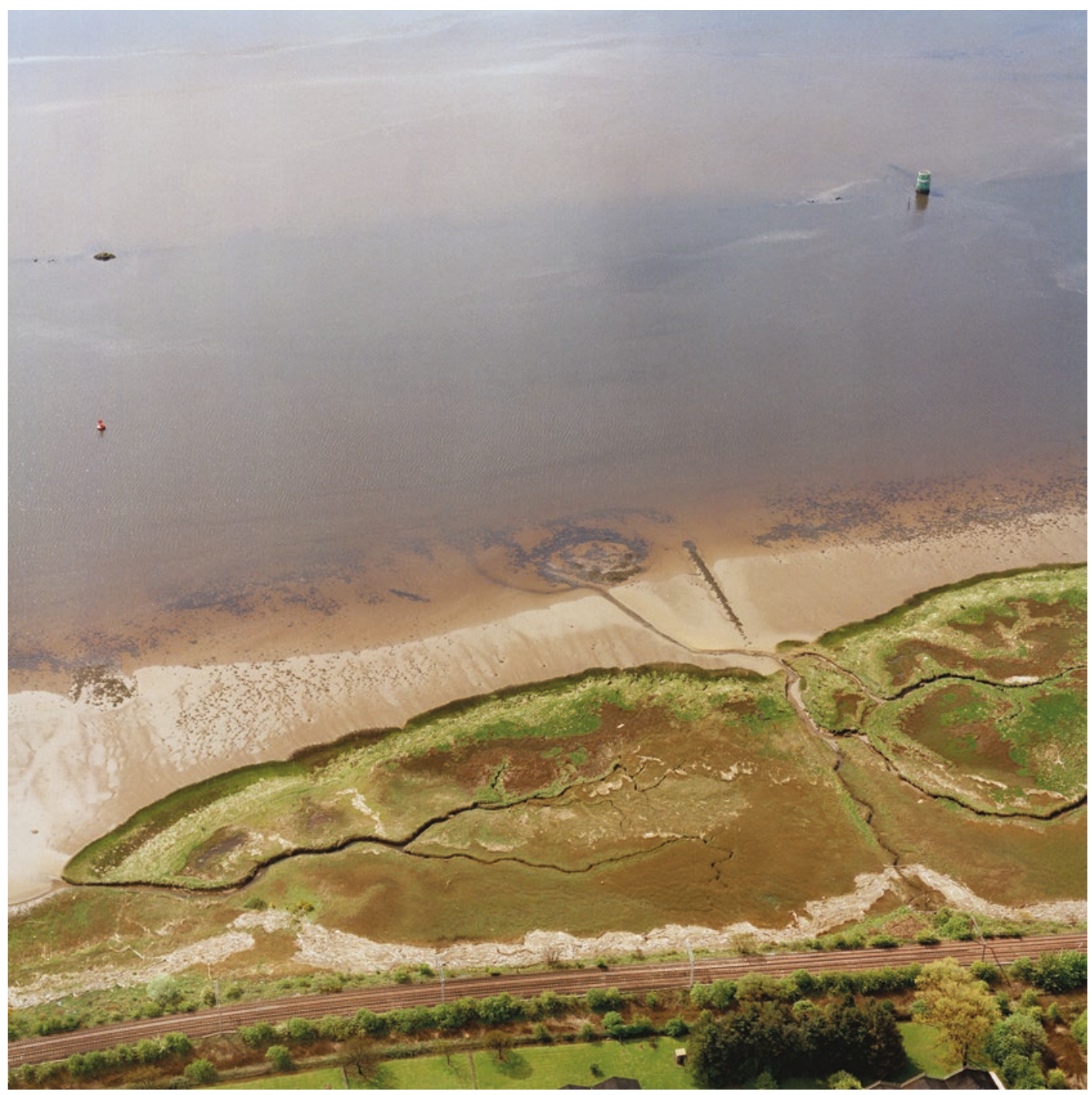

Fig. 10.5 Aerial photograph of Dumbuck crannog, dated at c. 2500 cal BP, showing the remains of a circular timber platform $35 \mathrm{~m}$ in diameter in the intertidal zone of the Firth of Clyde, near Glasgow. The platform of alder wood is surrounded by piles of oak, with a stone breakwater and timber-lined dock. Excavations in the late nineteenth century recovered querns, worked wood, and a $12 \mathrm{~m}$-long log boat. This is one of four crannogs in the Firth of Clyde with another four in the Beauly Firth and one on the West coast. Note that crannogs are also present in Scottish freshwater lake-edge settings, but these are not further discussed here. (C) Crown Copyright Historic Environment Scotland SC970218.

\subsection{Intertidal Footprints}

In a number of modern intertidal locations, fossilised human and animal footprints have been preserved and exposed. They were impressed in fine-grained sediments on mudflats that originally existed along ancient shorelines. Typically, these sediments build up rapidly as a sequence of thin, stratified layers, representing seasonal alternations between fine-grained sediments accumulated during summer and coarse-grained sediments in winter. Rapid sedimentaccumulation and subsequent natural consolidation ensures preservation of delicate features such as footprints, which are then exposed again 
in the modern intertidal zone by shoreward erosion, often as a series of stepped platforms with overlying layers of laminated sediments progressively peeled away to reveal earlier material. Most examples are from estuarine mudflats and cannot have been far from their contemporaneous coastlines. In such environments, the firmness of the sediment, gentle water conditions and rapid accumulation of sediment would have provided the best conditions for the preservation of surface imprints. The footprints themselves give details of age, sex, stature and physical condition, and the combination of footprints in trails suggests different types of activities.

The oldest examples are at Happisburgh, dated at $0.78-1$ million years (Ashton et al. 2014). They represent the oldest footprints outside Africa, and some of the earliest evidence for human occupation in Britain (Fig. 10.6). They were formed on the intertidal mudflat of a river estuary. Of 155 outlines, 49 were clear enough to indicate the direction of travel, and 12 were complete enough for detailed analysis, indicating at least five individuals including adults and children (Fig. 10.7).

The most extensive exposures of such finds are of much later date (broadly Mesolithic or Neolithic), at Formby Point (Huddart et al. 1999) with over 145 footprints (Fig. 10.8) and Goldcliff East, with over 270 human footprints, discussed in more detail below (Bell 2007). Many child footprints are present in both cases. In both areas, there are also many footprints of large animals such as deer (Fig. 10.9), aurochs and wolf or dog, and shore birds such as crane and oystercatcher. The Goldcliff footprints are dated as early as 7500 cal BP. At Formby, there are two stratigraphically separated groups of prints. One is dated c. $5750 \mathrm{cal}$ BP, and can, thus, be associated with Neolithic activity in the area, while the earlier set could be Mesolithic. At this latter site, one arthritic individual and a pregnant woman have been inferred. The trails suggest slower-paced activities by the women and children such as shellfish gathering, and a longer stride length for the men and imprints suggesting running after

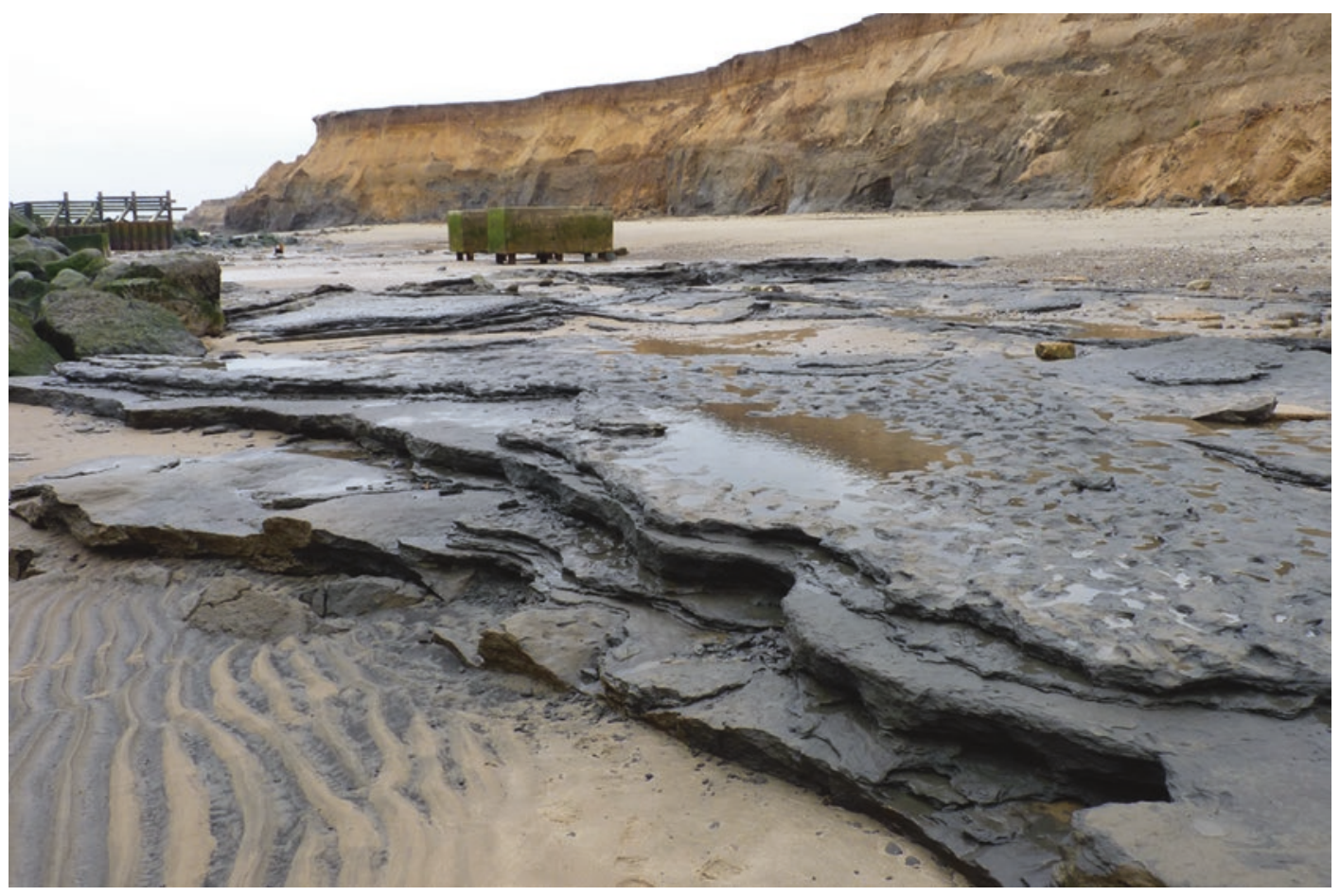

Fig. 10.6 General view of laminated silts in the Happisburgh intertidal zone with footprints of early humans. After Ashton et al. 2014 

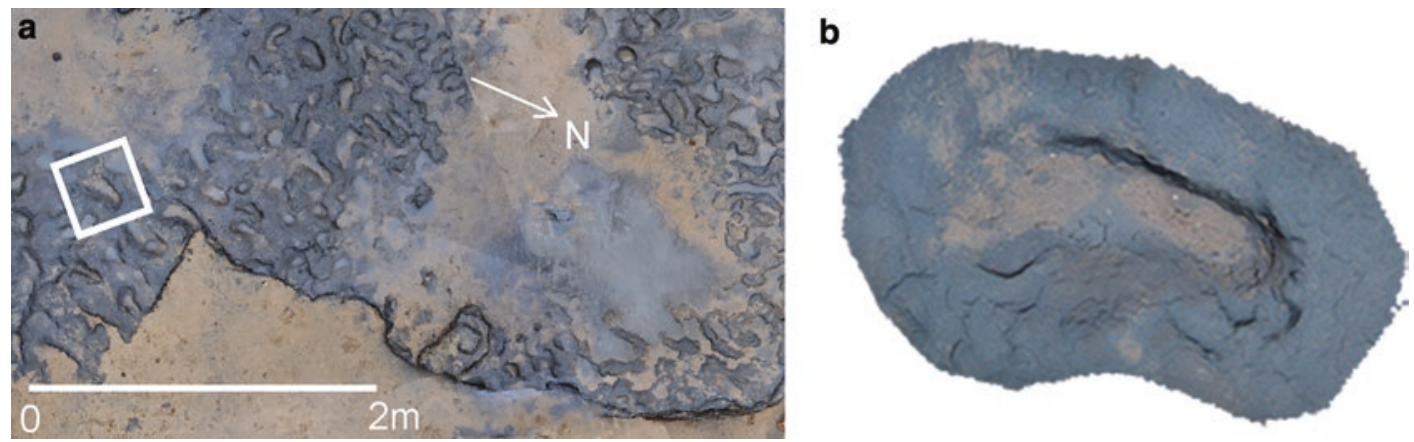

Fig. 10.7 (a) Plan view of the Happisburgh footprints. White rectangle indicates location of individual footprint; (b) close up of individual footprint. After Ashton et al. 2014. Photo of 3 (b) by Sarah Duffy (University of York), courtesy of Nick Ashton

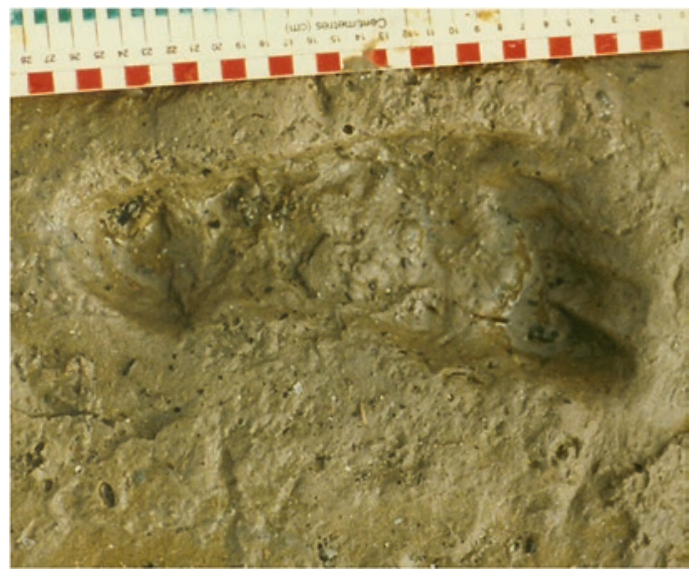

Fig. 10.8 Print in 6-4000-year-old mudflats at Formby Point of a human foot. Image courtesy of Silvia Gonzalez and David Huddart

hunted game. Another large group of Mesolithic human and animal footprints dated at about 7300 cal BP has recently been reported at Low Hauxley (Eadie and Waddington 2013).

\subsubsection{Goldcliff East}

Goldcliff East was a bedrock island with settlements on its flanks which were slowly and progressively engulfed by the sea and buried during the period 7500 to $6800 \mathrm{cal} \mathrm{BP}$. The finds are in the intertidal zone of the Severn River estuary where archaeological investigations have revealed traces of a succession of settlements and

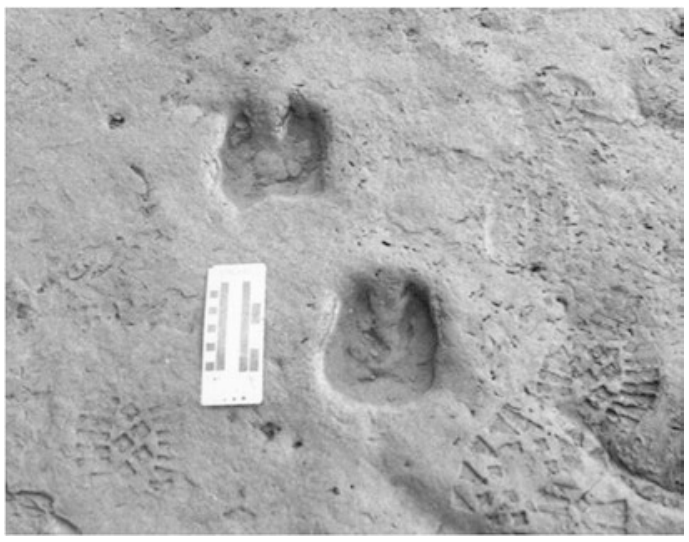

Fig. 10.9 Prints of red deer hooves at Formby. Note the difference between the deeply impressed prehistoric hoof prints and the modern boot prints in the superficial sediments. Image courtesy of Silvia Gonzalez and David Huddart

activity areas (Bell 2007). The most striking evidence is in the form of 270 human footprints that criss-cross the ancient mudflats and have been preserved within intercalated layers of sediment (Fig. 10.10; Scales 2007).

Among the human footprints, 21 individuals have been identified, providing tangible evidence for interactions between group members and patterns of movement between activity areas. Of these, four were adults (over 14 years old), seven were 'sub-adults' (11-14), two were older children (7-11), while the majority of the foot tracks (67\%) were made by eight young (3-6-year-old) children. The best preserved occurred in finegrained sediments indicating activity at the height 


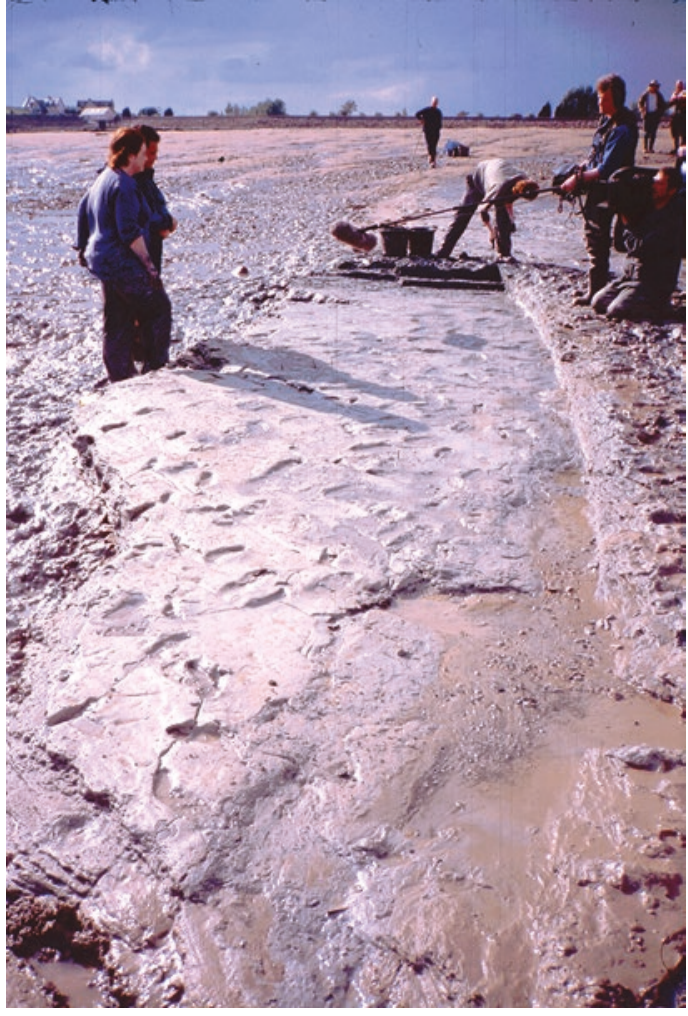

Fig. 10.10 General view of footprint tracks at Goldcliff East, Site C. Photo by Eddie Sacre

of summer. Some footprints form trails indicating the movements of a group of people across the mudflats (Figs. 10.11 and 10.12). This high proportion of child footprints highlights the activities of group members who are usually invisible in the archaeological record and are here seen to be fully engaged with the life of the community from an early age.

There are also 149 recorded mammal tracks, mostly of red deer, but including a small number of roe deer, aurochs and a canid, probably a dog. Over 70 bird prints include cranes, grey herons, gulls, oystercatchers and terns.

The artefacts include lithics and a small number of pieces of worked antler and bone. Worked wooden artefacts include cut pieces of roundwood (diameter $<30 \mathrm{~mm}$ ) and other fragments that may represent pointed stakes, seven probable hand-held tools of uncertain function and possible fragments of fish weirs (Brunning 2007).
Charred seeds, fruits and nuts, faunal remains of mammals and fish, and pollen and insect evidence of environmental conditions and diet are all well preserved in the anaerobic sediments. These finds indicate exploitation in most seasons of the year but especially in late summer and autumn, and provide evidence for the use of fire to manipulate the local vegetation, probably to increase the abundance of woodland-edge plant resources

\subsection{Underwater Sites}

\subsubsection{Bouldnor Cliff: A Submerged Mesolithic Site}

This is at present the most intensively explored underwater Stone Age site in Britain, located in southern England offshore of the northern coastline of the Isle of Wight. Here traces of human activity in a former inland environment are preserved in and below a peat layer dated to c. 8100 cal BP with Mesolithic stone tools showing affinities with France and a large collection (some 80 pieces) of worked wood (Figs. 10.13 and 10.14). An unusual find demonstrating the excellent conditions of preservation is a piece of twine or string made from plant fibres (Fig. 10.15).

The site lies $12 \mathrm{~m}$ below mean sea level and is associated with a drowned forest. The submerged landscape is a $1 \mathrm{~km}$-long bench eroding out from near the foot of a cliff. Five distinct locations of archaeological remains have been identified so far, associated with a variety of environmental features including streams, sand bars, woodland and fen. Above the archaeological layer, there are estuarine silts that filled the pre-existing valley during the later stages of sea-level rise (Momber et al. 2011; Momber and Peeters 2017).

The wooden material includes oak timbers worked by tangential splitting, a technique not previously recorded in Britain earlier than the Neolithic period some 2500 years later (Taylor 2011). Some of these timbers appear to represent the edge of a platform or collapsed structure.

Extraction of ancient DNA from sediments (sedaDNA) in a sealed context indicates the pres- 


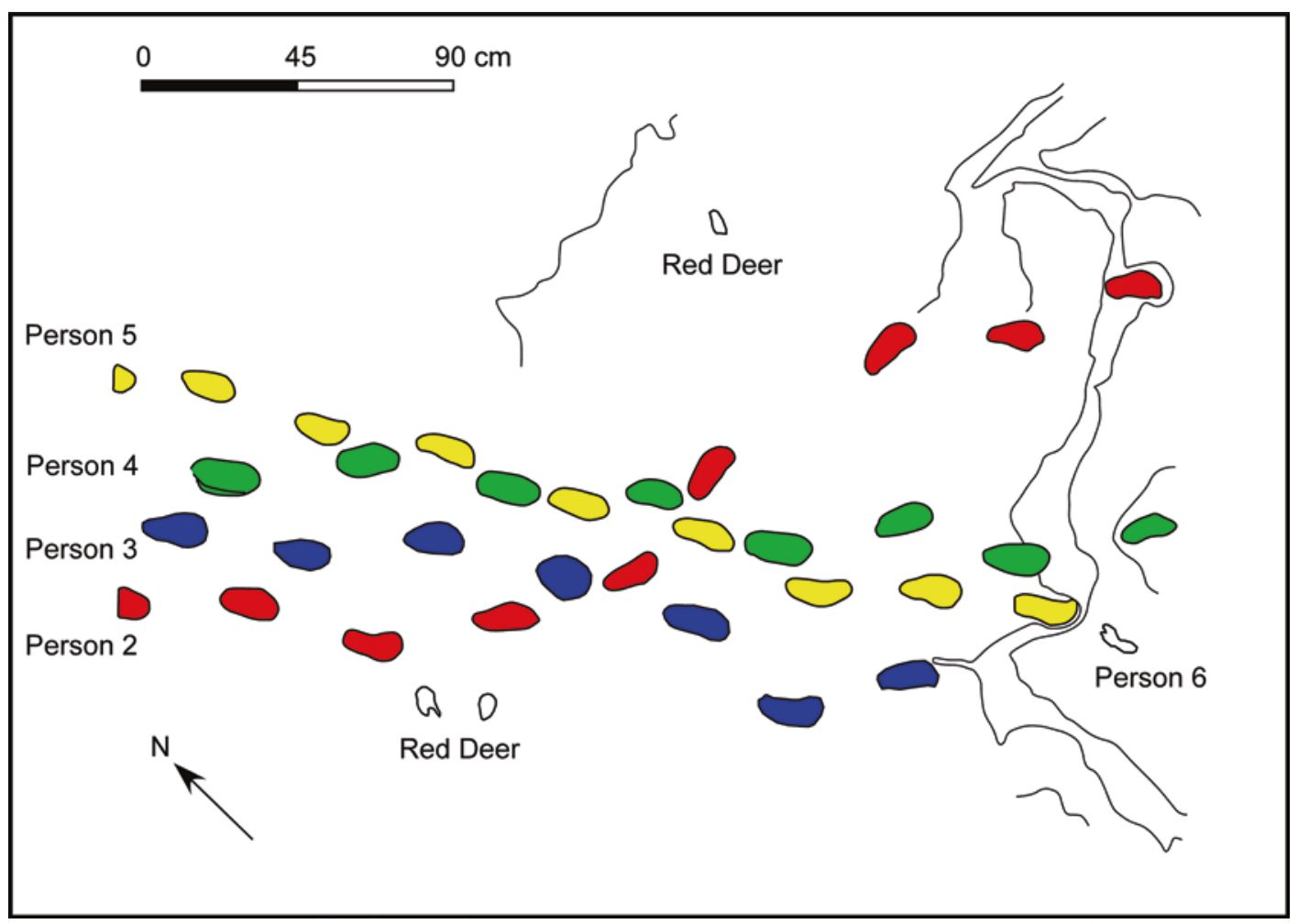

Fig. 10.11 Goldcliff East, Site E. Plan of the trails of Persons 2-5. The footprint of Person 6 is on a lower lamination. Also shown are hoof prints of red deer. After Scales 2007

ence of cultivated einkorn wheat 2000 years before agriculture is conventionally supposed to have reached Britain (Smith et al. 2015). If confirmed, this will reinforce the evidence from the wooden artefacts for the precocious arrival of 'Neolithic' traits at a time when sea levels were lower than present, prime territory in coastal locations that are now submerged was still available, and connections with the European mainland were still easily facilitated along coastlines that connected southern England with northern France (see also Anderson-Whymark et al. 2015).

\subsubsection{Deep-Water Finds in the North Sea}

Isolated finds have been recovered during trawlerfishing and industrial activities in the British sector of the North Sea. One of the most famous is the barbed antler harpoon from the Leman and
Ower Banks (Fig. 10.16). When brought up in the net of a trawler boat in 1932, this excellently preserved item was fixed in a lump of peat, which was originally interpreted as an item lost while fishing along the edge of a now-submerged lake (Godwin and Godwin 1933). The peat was originally dated at $7500 \mathrm{cal}$ BP $(8422 \pm 170)$ (Godwin and Willis 1959), but direct AMS (Accelerator Mass Spectrometry) dating of the specimen itself later returned a date of 13,500 cal BP $(11,740 \pm 150)$ (Bonsall and Smith 1989; Hedges et al. 1990). A similar find of a harpoon, though less well known, was brought up in c. 1950 in a fishing net $2 \mathrm{~km}$ offshore of the Norfolk coast near Trimingham.

Other finds include a worked flint recovered from coring of the seabed at a water depth of $-143 \mathrm{~m}$ during oil exploration on the Viking Bank in the northern sector of the North Sea (Long et al. 1986), and worked flint and remains of fauna (predominantly mammal bones, mam- 


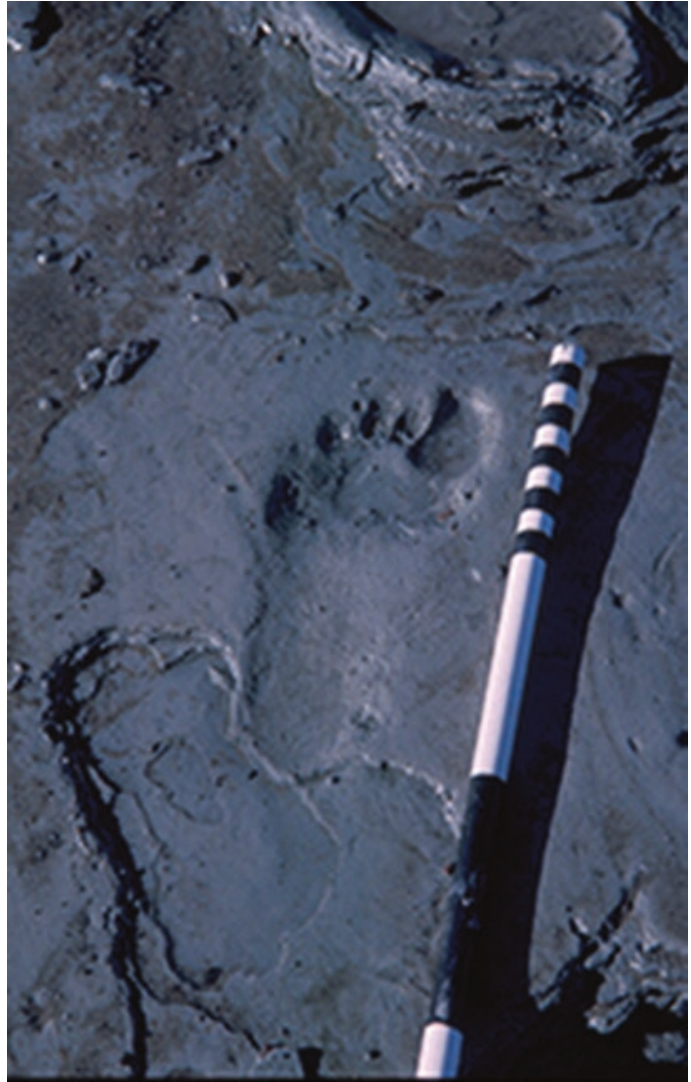

Fig. 10.12 Well-preserved footprint of Person 6 at Goldcliff East, Site E. Photo by Eddie Sacre moth teeth and tusks) discovered during industrial gravel extraction and offshore fishing (Wessex Archaeology 2007; Tizzard et al. 2014).

One other notable find is the two Neolithic polished axes reported from the Dogger Bank. They were given to the Craven Museum in Skipton by a private collector in 1934 and Van de Noort (2014, p. 59) sees no reason to doubt the authenticity of their provenance as items brought up by Yorkshire fishermen, although the precise location of the discovery within the general area of Dogger Bank is unknown. A similar find of two polished axes of Michelsberg type has been reported from the Brown Bank further south in the North Sea (Peeters and Amkreutz, Chap. 8, this volume). The age of these items cannot be earlier than about $6300 \mathrm{cal} \mathrm{BP}$, and sea level by that time would have largely submerged these locations or at best exposed them as low islands at low tide. It is unclear whether these finds represent visits to these islands when they were above water, are objects lost overboard when fishing on the banks, or are deliberate votive offerings deposited in the sea in the manner more commonly recognised in the Bronze Age (see above). At any rate, they are evidence for sea journeys over considerable distances in the southern North Sea at this time.
Fig. 10.13 Worked flints recovered from submerged peat deposits at Bouldnor Cliff. Scale in centimetres. Photo by Maritime Archaeology Trust

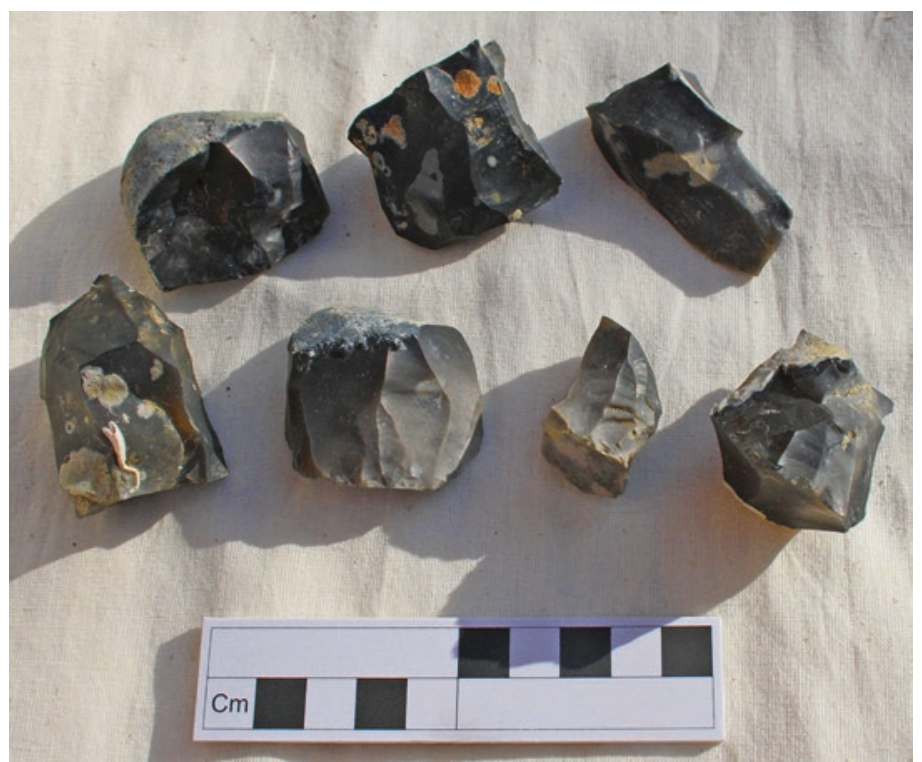


Fig. 10.14 Piece of worked timber from Bouldnor Cliff, showing the freshly exposed condition of the wood with deep cut marks, immediately after removal from the surrounding peat deposits. Photo by Maritime Archaeology Trust

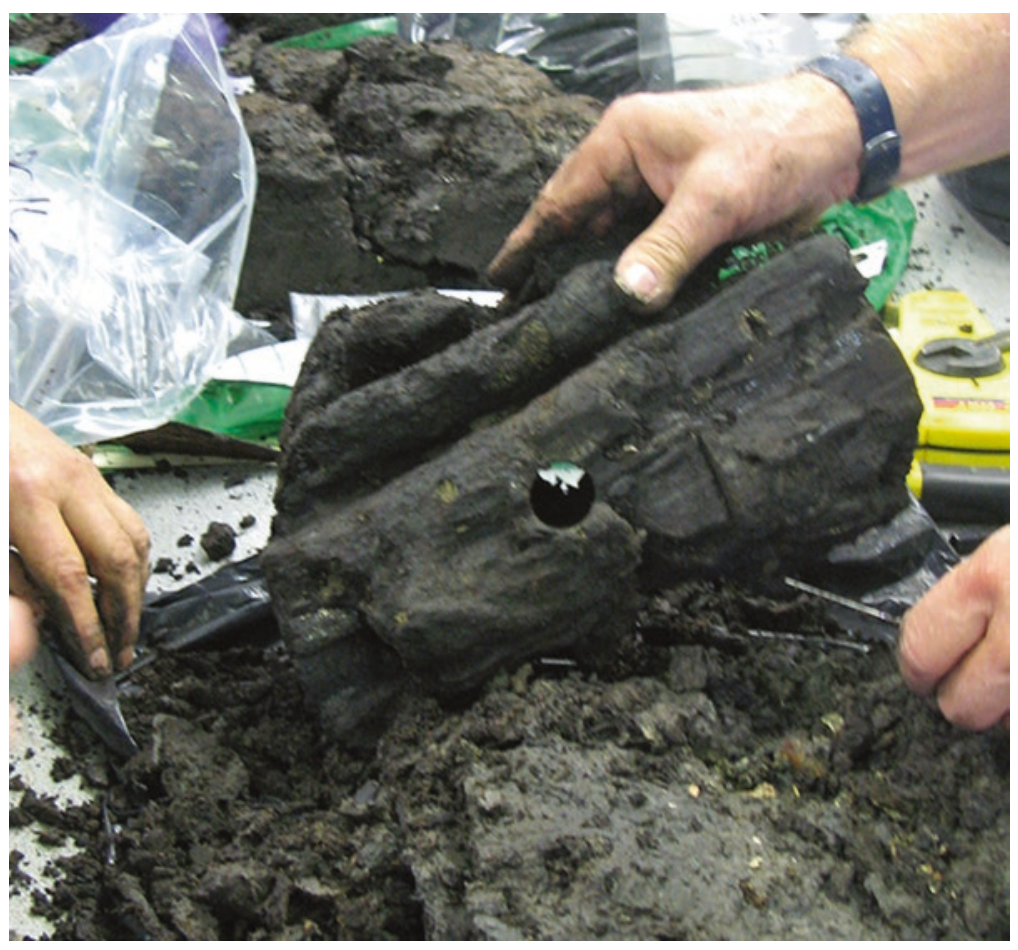

\subsubsection{Area 240: Palaeolithic Artefacts in Their Palaeoenvironmental Context}

This site was first identified when flint artefacts and faunal remains were found in aggregate stockpiles at a harbour in the Netherlands. Further monitoring (Fig. 10.17) established that the artefacts were dredged from a specific locale within marine aggregate license Area 240,11 km off the English coast, at depths of 18 to $35 \mathrm{~m}$. Geophysical survey and coring were used to obtain further information on the sediments and landforms associated with the artefacts and their date. Additional samples of bulk sediment were removed from the seabed using a combination of a remotely operated underwater camera for site selection, a beam trawl and a clamshell grab. This resulted in the recovery of additional flint artefacts and faunal remains and established the stratigraphic relationship between the archaeological finds and the dated sediment sequence (Tizzard et al. 2011, 2014, 2015; Bicket et al. 2014; see also Pater, Chap. 26, this volume).
More than 120 specimens, including handaxes (Fig. 10.18) and Early Middle Palaeolithic Levallois flakes, have now been recovered from this locality. Most of the artefacts are associated with stratified floodplain deposits of a river estuary dated to 250,000 $200,000 \mathrm{BP}$, an age that is consistent with welldated, technologically similar artefact assemblages found elsewhere in Britain and Continental Europe. Around 20\% of the assemblage exhibits Levallois technology further supporting a post-300,000 date for some or all the material. Some of the faunal material (e.g. Fig. 10.19) can be associated with earlier channel deposits dating back to more than 500,000 $\mathrm{BP}$, and a smaller group of artefacts occurs in later sediment infills dating to $40,000-30,000$ BP.

This early Palaeolithic assemblage has survived multiple cycles of sea-level change during which the area has been exposed and submerged several times. The results of the archaeological fieldwork indicate that many of the Stone Age items are in their original place 
of deposition. In addition, they demonstrate that it is possible to recover archaeological material and contextual environmental information from deeply submerged sites far off the

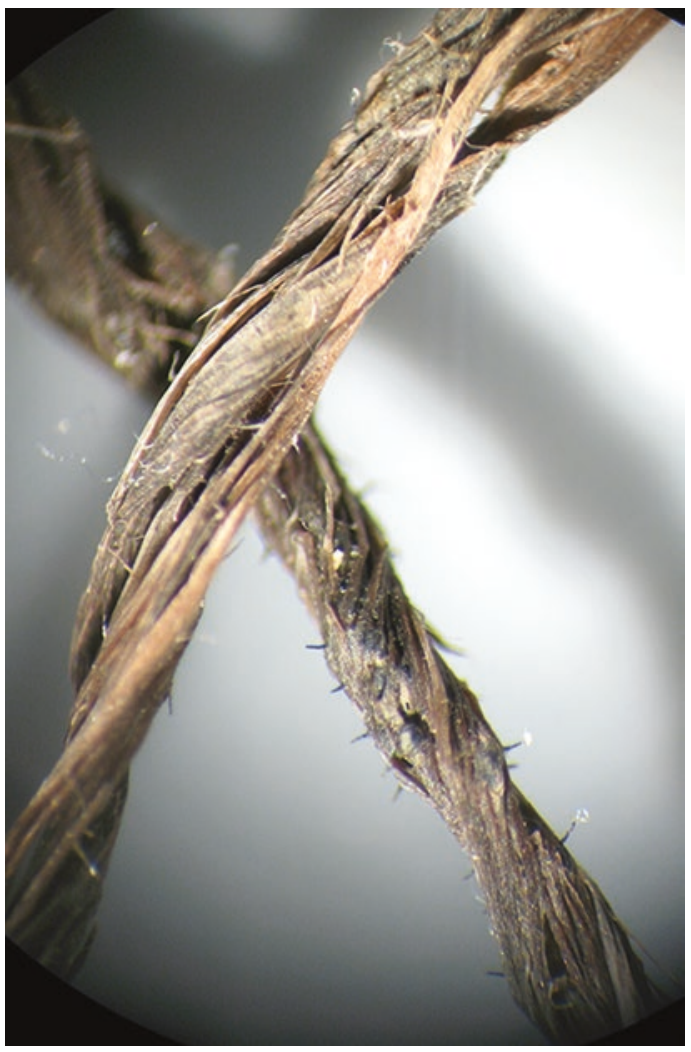

Fig. 10.15 Close-up of a piece of string from Bouldnor Cliff made by twisting together of plant fibres. It is about $10 \mathrm{~cm}$ in length, with a diameter of $1-2 \mathrm{~mm}$. The fibres could be from nettle, wild clematis, blackberry or honeysuckle. Materials were identified by David Robinson. Photo by Maritime Archaeology Trust present coast. This is the only such site identified in the North Sea to date and represents one of the oldest submerged prehistoric sites known anywhere in the world. The material highlights the possibility of further discoveries especially linked to inundated Quaternary floodplains and river systems, which are common around northwest European coasts.

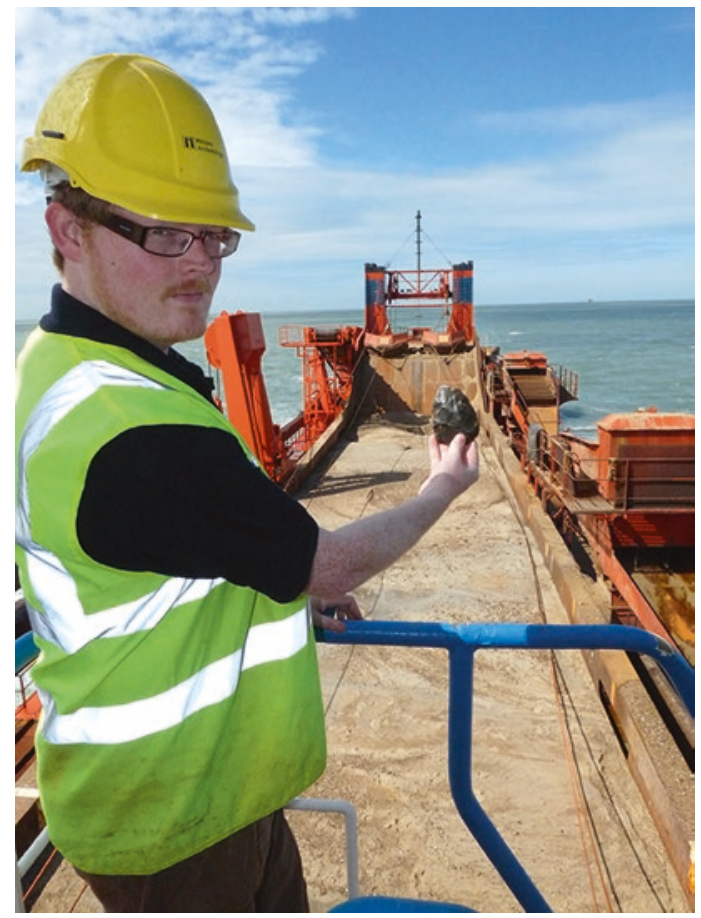

Fig. 10.17 Archaeologist Andrew Bicket holding a handaxe recovered during monitoring work carried out on behalf of Hanson Aggregates Marine Limited on board one of their vessels. (OWessex Archaeology

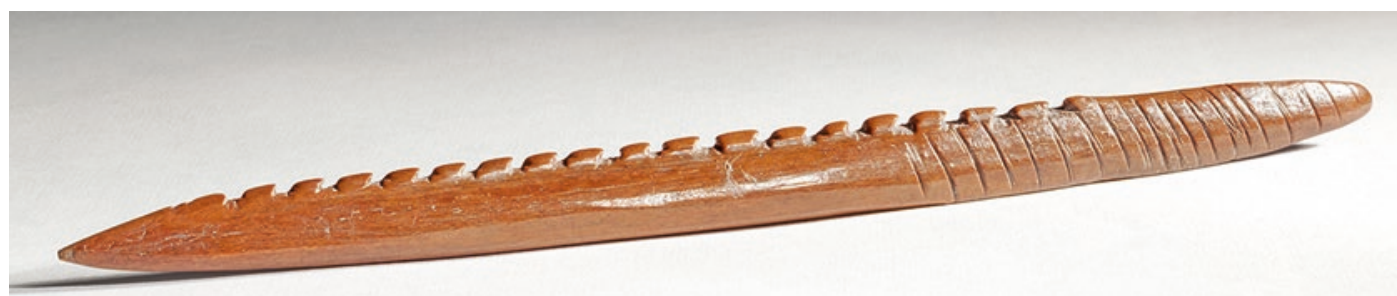

Fig. 10.16 The barbed point made of antler recovered in 1932 by the Colinda fishing vessel. Length of specimen is $219 \mathrm{~mm}$. Found at Leman and Ower Banks. (C) Norwich Castle Museum and Art Gallery. Reproduced by permission 


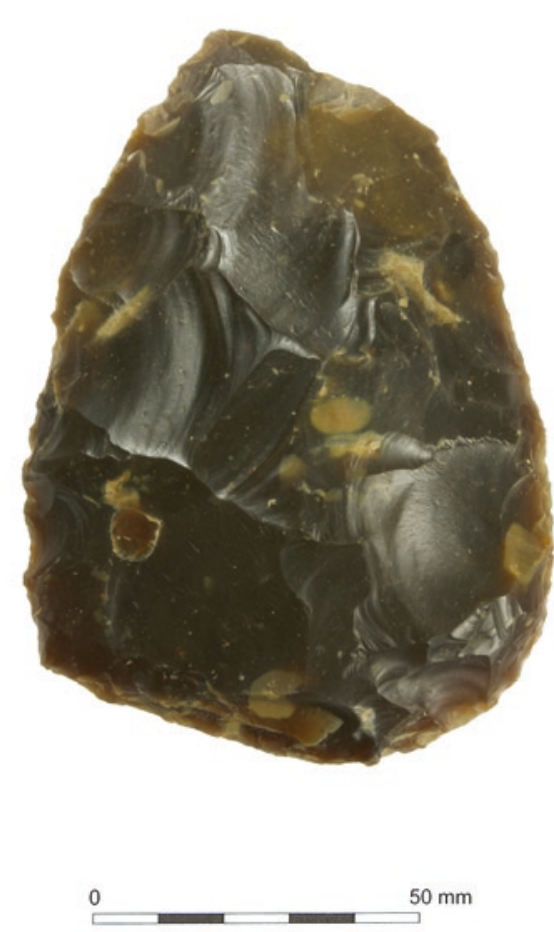

Fig. 10.18 Bifacially worked handaxe from A240. This is one of over 30 examples of this characteristic artefact type from the Area 240 locality dated to 250-200,000 years ago. Many, like this one, have sharp edges and are in mint condition, indicating that they have remained undisturbed in their original position. Scale in centimetres. (C) Wessex Archaeology

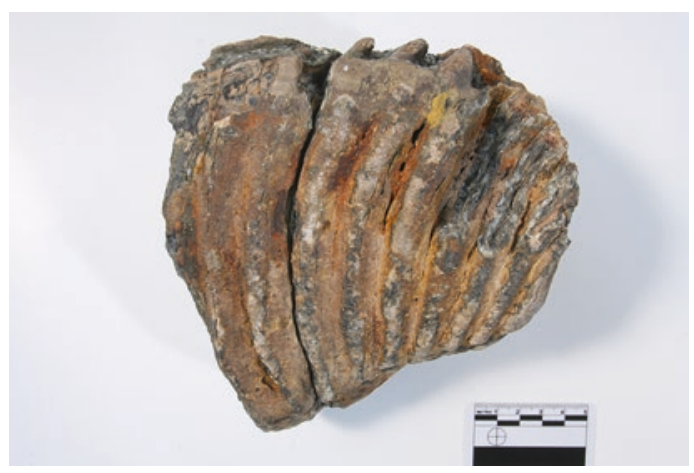

Fig. 10.19 Tooth of a woolly mammoth recovered from the A240 site. Many fossilised remains of terrestrial mammals have been recovered, including bones of horse, bison and reindeer, most of which are dated to about 500,000 years ago. Scale in centimetres. (C) Wessex Archaeology

\subsection{Discussion}

The British underwater material covers a wide range of ages, water depths and types of material evidence, sometimes with excellent conditions of preservation. Intertidal finds dominate numerically and some of the best evidence is associated with or sealed beneath submerged forests or peat deposits that are exposed at low tide, in some cases at considerable depth and distance offshore. These include settlement and activity areas, often with preservation of worked wood, and human and animal footprints. Some of these intertidal finds, exposed only at extreme low spring tides, are further offshore, at a greater depth below mean sea level, and of earlier date, than many of the famous, permanently submerged underwater sites of the Baltic (See Bailey et al. Chap. 3, this volume; Nilsson et al., Chap. 4, this volume; Jöns et al., Chap. 5, this volume) and suggest an untapped potential for new research.

In considering this material as a whole, two sorts of questions come to the fore. The first is the nature of the strategies that can be adopted to achieve purposeful investigation and discovery of new underwater archaeological material, especially in more deeply submerged locations. The second question is what sorts of new information might be obtained from underwater investigation that cannot be found on land, and what new themes such information opens up for investigation into the organisation and development of earlier prehistoric societies. The two types of questions are closely linked; without the intellectual justification for new field investigations, there would be little motivation to undertake them and little appetite to develop new methods and marshal the necessary resources. The currently available evidence provides significant pointers as to the direction of future investigations.

\subsubsection{Research Strategies}

Taking first the question of how to systematise the search for new information, it is important to emphasise that all the finds reported here have 
been discovered by chance exposures or dredged up by fishing and industrial activity. Most are in the intertidal zone or in very shallow water, where the age of the material is relatively young (mostly Holocene or Late Glacial). This is also the zone where the chances of discovery are highest, but where the risks of destruction are also very high. The fact that so much evidence, some of it very old as in the case of the Happisburgh footprints, has been exposed in such a geologically active zone over many centuries and even millennia is notable. It demonstrates that archaeological evidence is not necessarily doomed to destruction in the early stages of marine inundation, when the destructive forces of wave action in the surf zone and shallow-water currents are at their greatest. As always in dealing with underwater preservation, local factors are paramount, including minor variations in topography, shoreline configuration and exposure to wind and waves. Accumulation of marine sediments or layers of peat that provide protective cover is clearly a key factor that can contribute to preservation of old land surfaces, regardless of the erosive power of waves and currents. Discovery, of course, depends on intermittent exposure of the underlying deposits by natural erosion or human activities. Almost by definition, such sites when first discovered are already in the process of being exposed to destructive forces. If allowed to continue unabated, continued erosion will lead to further destruction and loss unless the material is covered up again by further accumulation of protective sediments.

The challenge then is to work out how to search for new archaeological material, rather than relying on chance discoveries, and especially how to deal with the challenge of discovering archaeological finds in more deeply submerged areas. New research is currently evolving along two separate lines of enquiry. One is to develop improved methods of mapping and remote sensing that can give detail to the nature of the now-submerged terrestrial landscape and identify target features worth investigating more closely with remotely operated vehicles and cameras, coring and diving. A good example of new work along these lines is the new mapping of
Doggerland (Gaffney et al. 2017), in effect an extension of the earlier landscape reconstructions pioneered by the Gaffney team using seismic records from the hydrocarbon industry, but with acoustic techniques more appropriate to the shallower deposits of the seabed that inform on the recently submerged human landscape, followed up by coring of sediments in target areas identified by the mapping. Whether this will identify archaeological materials remains to be seen but the recovery of sedaDNA from sealed terrestrial contexts will add new information on the terrestrial plant and animal life present before submergence.

The other strategy is to work from known finds recovered by chance exposure, trawlerfishing or other industrial activity, and use these to target areas worth more detailed investigation. The success of such an approach has already been indicated by the A240 finds discussed above. Bynoe et al. (2016) draw attention to the detailed archive of records that can help to pinpoint the location of faunal remains recovered from the seabed by trawler fishing. As the A240 discoveries show, if materials disturbed on the seabed and recovered during the course of industrial operations can be traced back to their original position, this may indicate more deeply embedded material in stratified sediments with opportunities for dating, palaeoenvironmental analysis and preservation of organic materials. There is no doubt that large quantities of faunal remains and artefacts are preserved on the seabed of the North Sea, and every reason to suppose that more awaits discovery, with new opportunities for systematic retrieval.

Both strategies are currently being focussed on deeper areas of the submerged shelf and hence on landscapes that extend further back in time and to environmental settings quite different from those currently exposed near the present-day shoreline. Potentially, these offer a much greater payoff in terms of new information. But they also pose greater logistical challenges and costs than working in shallow water. Equally, there is no reason why similar strategies should not be applied in shallower water, with simpler technical requirements and the prospect of recovering 
significant new data. The existing evidence from intertidal submerged forests and peat deposits indicates that these increase in age with increasing distance and depth from the modern shoreline and that this trend continues offshore. It should be possible through acoustic survey and diver inspection to follow these features into deeper water and to search for channels or other features that have exposed earlier terrestrial deposits beneath the overlying marine sediment, as is the case at Bouldnor Cliff. All the indications are that extensive areas of submerged forest and associated land surfaces exist at greater depth and may be in a less disturbed condition than those known from the present-day intertidal zone. The feasibility of underwater exploration to extend investigations of known intertidal features to the offshore zone has already been demonstrated in the Wootton Quarr project (Edwards and Dix 2012).

Many of the intertidal finds reported in this chapter were found low in the intertidal zone and were investigated on foot during the very short windows of opportunity offered by extreme low tides. An alternative strategy in such circumstances would be to investigate these deposits when covered by the sea at high tides, using wellestablished techniques of diver inspection, survey and excavation. Prediction of target areas for closer investigation using the Danish fishing site model, suitably adapted to English coastal geomorphology and tidal conditions, is another possibility (Hall 2014).

\subsubsection{Research Themes}

Turning to substantive themes of early development that are brought uniquely into focus by the underwater evidence, four stand out. The first is the quality of preservation of organic materials and other evidence that would not normally be recovered, or only rarely so, from terrestrial deposits, and their potential to push back in time technological and economic innovations traditionally associated with the Neolithic or later periods. Wooden artefacts are especially well represented and indicate economically signifi- cant activities such as building structures, fish traps, landing stages for water craft, and sometimes remains of the boats themselves. Most of the British finds are relatively late in date (Neolithic or Bronze Age) and perhaps occasion relatively little surprise given conventional expectations about the nature of technological progress. But more deeply submerged sites take the story further back in time. At Bouldnor Cliff, for example, there is evidence of worked timbers revealing techniques of wood working and the presence of cultivated cereals some 2000 years earlier than the earliest evidence currently known from sites on land.

It should be emphasised, however, that submergence by marine inundation does not guarantee the survival of wood or other organic materials. If the archaeological site and its artefacts had been exposed to subaerial weathering for long enough before being covered by marine sediments, then organic materials such as wood would have disappeared. Rapid inundation and protective cover of anaerobic sediments is the key to the survival of such materials. Conversely, even without organic preservation, other features such as pits and postholes may be preserved under a protective cover of marine sediments, as noted above on the Essex coast.

A second theme is the deeper history of economic adaptations and especially those associated with the exploitation of marine resources that might be revealed at coastal sites that are now deeply submerged. Conventional archaeological evidence in the form of food remains of marine mollusc shells or bones of fish and sea mammals is not yet known from underwater sites, except for occasional hints from sites on the present-day coast or in the intertidal zone, mainly because the underwater settlement sites where such remains might be expected have not yet been discovered. Artefacts that can be uniquely associated with exploitation of aquatic resources, such as the Leman and Ower harpoon, are rare and at best ambiguous with respect to their function. The Westward Ho! shell midden provides a hint that such deposits can survive inundation and erosion at the shore edge, and other food remains including plant material should have a 
good chance of preservation in submerged deposits. There is certainly every reason to expect that marine resources should have left evidence of their consumption from the very earliest period of occupation in Britain. Shellfish in the intertidal zone, fish and crustacea in natural rock pools and traps, and sea mammals and sea birds that come ashore for breeding or are beached by storms would all be accessible along shorelines from the earliest period by our earliest hominin ancestors without the need for specialised equipment or boats. Proxy evidence from stable isotope signatures in human bone, as in the Paviland example discussed earlier, provides another potential line of investigation where human skeletal remains are present.

A third theme is the use of coastlines and travel by boat as pathways of communication and population dispersal. The evidence from Norway demonstrates how rapidly people can move into ice-free coastal zones with the aid of boats and a combination of hunting on land and at sea (Bjerck 2008; Glorstad et al., Chap. 6, this volume). Similarities in some of the earliest flaked stone spearheads found in Scotland with those in northern Germany and southern Scandinavia hint at just such a pattern of dispersal and economic adaptation around the now-submerged coastlines of northern Doggerland, perhaps as early as 14,000 years ago. Certainly, by the time that northern coastlines and their coastal archaeological sites become visible from about 10,000 years ago onwards, the distribution of sites around the northern and western coasts of Britain suggests a ready facility for inshore sea-travel and coastwise communication (Waddington 2015). Similarities between Mesolithic artefact types in southern England and northern France similarly suggest patterns of communication around the coastlines that connected the two regions before sea-level rise finally severed the land connection between them.

A final theme of topical interest is the impact of sea-level rise on societies living in the affected coastal regions, and the socio-economic, demographic and psychological impact of such changes (Leary 2015). According to one interpretation of the British evidence, the appearance of sedentary or semi-sedentary coastal settlements with evidence of marine exploitation in northern Britain may represent a response to the loss of territory by sea-level rise (Waddington 2007, 2015). However, such a view presupposes that similar settlements were absent on earlier and now-submerged coastlines, and that their appearance on modern shorelines at a later date is a response to the pressures imposed by loss of preexisting resources, rather than simply a matter of differential preservation or visibility. It also relies on the questionable assumption that people in earlier periods avoided coastlines and their attendant ecological and economic advantages and preferred to concentrate on terrestrial resources until forced to change by loss of existing land.

Much depends on the pace and scale of land loss in relation to pre-existing population densities. Did the loss of large areas of land happen rapidly enough to stimulate or compel the adoption of new patterns of settlement and new economic and social arrangements? Or was the progressive abandonment of former territory slow enough to be accommodated by orderly retreat without major dislocation of existing social and economic arrangements? Some progress towards answering these questions could be achieved by simulations based on simple demographic assumptions and assessments of land area lost with progressive sea-level rise (see, for example, Williams et al. 2018 for an analysis of a similar set of changes around the Australian coastline).

To what extent was loss of land compensated by new advantages and opportunities, for example the increased productivity of fishing grounds in the shallow seas created by inundation of the continental shelf, or the opening up of new subsistence opportunities in the hinterland by climatic warming? What impact did changes in the coastal zone have on patterns of exploitation, site distributions and settlement in the British hinterlands, and can changes in the late Upper Palaeolithic and early Mesolithic archaeological record in these hinterlands be attributed in any way to social impacts resulting from loss of territory on the retreating coastline? The fact that Neolithic cultural traits, if not actual Neolithic people expand- 
ing from continental Europe, were present offshore and in now-submerged lowlands, raises the further question of how far sea-level rise is implicated in the expansion of agricultural economies and the interactions between indigenous and incoming populations. Other climatic and environmental changes may well have been involved in addition to sea-level rise, so that disentangling the relative influence of these different variables is likely to be a challenging proposition. If the evidence currently available is scarcely sufficient to move the debate about the human consequences of sea-level rise much beyond speculation, simply to pose these sorts of questions should stimulate new ideas, new lines of enquiry and new observations. Submerged landscapes, as Sturt et al. (2017) have noted, are good to think with, and the benefits of such a perspective ought to stimulate new investigations not only of the underwater archaeological record, but the archaeological record on land, and ultimately the relationship between the two of them.

\subsection{Management of the Underwater Cultural Heritage}

The underwater and on-land heritage is protected by legislation at UK Government level, in particular the National Heritage Act of 1983, as amended in 2002 to include underwater archaeology in UK territorial waters. The 2002 National Heritage Act provides additional protection of the underwater cultural heritage through the planning regime. Where underwater cultural heritage is identified through Environmental Impact Assessment, marine licences can be withheld unless appropriate archaeological mitigation is put in place. This may include an exclusion zone, monitoring, survey or excavation (Bicket et al. 2014; see also Pater, Chap. 26, this volume).

Implementation is devolved to separate Executive Agencies in England, Scotland and Wales. The Historic Buildings and Monuments Commission for England, also known as English Heritage, was established in 1983. In 2015, the responsibility for maintaining historic buildings and collections was hived off as a separate charity retaining the title of English Heritage, and responsibility for research and maintaining records of archaeological sites was established under the new title of Historic England (HE), which maintains the National Record of Historic England (formerly known as the National Monuments Record). HE is currently answerable to the UK Government Department for Culture, Media and Sport. The Scottish equivalent is Historic Environment Scotland (since 2014 combining the functions of Historic Scotland and the Royal Commission on the Ancient and Historical Monuments of Scotland). Historic Environment Records are accessed through Canmore (https:// canmore.org.uk/), and HES has been accredited as a Marine Environmental Data \& Information Network (MEDIN) Data Archive Centre (DAC) (https://www.oceannet.org/about/data-archivecentres), as a repository for marine historic environment data since 2015. There is a similar division of labour in Wales between CADW, responsible for the historic environment and answerable to the Welsh Government Department of Economy, Science and Transport, and The Royal Commission on the Ancient and Historical Monuments of Wales (RCAHMW), responsible for research and maintenance of the National Monuments Record of Wales.

Acknowledgements All authors have contributed to the compilation of the site record in the SPLASHCOS Viewer on which this chapter is based. GB analysed the site records and wrote the text, with contributions from GM, MB, LTz, AB and AH. We thank Nic Flemming and Fraser Sturt for a critical reading of the text and helpful comments.

\section{References}

Allen MJ, Gardiner L (2000) Our changing coast: A survey of the intertidal archaeology of Langstone Harbour, Hampshire. Council for British Archaeology, York

Allington-Jones L (2015) The Clacton spear: the last 100 years. Archaeol J 172(2):273-296

Anderson-Whymark H, Garrow D, Sturt F (2015) Microliths and maritime mobility: a continental European-style Late Mesolithic flint assemblage from the Isles of Scilly. Antiquity 89(346):954-971 
Ashton N, Lewis SG, De Groote I, Duffy SM, Bates M, Bates R, Hoare P, Lewis M, Parfitt SA, Peglar S, Williams C, Stringer C (2014) Hominin footprints from Early Pleistocene deposits at Happisburgh, UK. PLoS One 9(2):e88329. https://doi.org/10.1371/ journal.pone.0088329

Balaam ND, Bell MG, David AEU, Levitan B, Macphail RI, Robinson M, Scaife RG (1987) Prehistoric and Roman-British sites at Westward Ho!, Devon: archaeological and palaeoenvironmental surveys 1983-1984. In: Balaam ND, Levitan B, Straker V (eds) Studies in palaeoeconomy and environment in Southwest England, British archaeological reports British series 181. B. A. R., Oxford, pp 163-264

Ballin TB (2017) Rising waters and processes of diversification and unification in material culture: the flooding of Doggerland and its effect on north-west European prehistoric populations between ca. 13000 and 1500 cal BC. J Quat Sci 32(2):329-339

Ballin TB (2019) Identification of Scottish Late Upper Palaeolithic industries by detailed technological analysis. Mesolithic Miscellany 27(1)

Ballin TB, Saville A, Tipping R, Ward T (2010) An Upper Palaeolithic flint and chert assemblage from Howburn Farm, South Lanarkshire, Scotland: first results. Oxf J Archaeol 29(4):323-360

Ballin TB, Saville A, Tipping R, Ward T, Housley R, Verrill L, Bradley M, Wilson C, Lincoln P, Macleod A (2018) Reindeer hunters at Howburn Farm, South Lanarkshire. Archaeopress, Oxford

Barton RNE (1992) Hengistbury Head, Dorset, Volume 2: The late upper palaeolithic and early mesolithic sites, Monograph 34. Oxford University Committee for Archaeology, Oxford

Bates MR, Nayling N, Bates R, Dawson S, Huws D, Wickham-Jones C (2013) A multi-disciplinary approach to the archaeological investigation of a bedrock-dominated shallow-marine landscape: an example from the Bay of Firth, Orkney, UK. Int J Naut Archaeol 42(1):24-43

Bell M (2007) Prehistoric coastal communities: the Mesolithic in Western Britain, CBA research report 149. Council for British Archaeology, York

Bell M (2013) Intertidal survey and excavation. In: Menotti F, O'Sullivan A (eds) The Oxford handbook of wetland archaeology. Oxford University Press, Oxford, pp 467-481

Benjamin J, Bicket A, Hale A, Anderson D (2014) A multi-disciplinary approach to researching the intertidal and marine archaeology in the Outer Hebrides, Scotland. J Island Coast Archaeol 9:400-424

Bicket A, Tizzard L (2015) A review of the submerged prehistory and palaeolandscapes of the British Isles. Proc Geol Assoc 126(6):643-663. https://doi.org/10.1016/j. pgeola.2015.08.009

Bicket A, Firth A, Tizzard L, Benjamin J (2014) Heritage management and submerged prehistory in the United Kingdom. In: Evans AM, Flatman JC, Flemming NC (eds) Prehistoric archaeology on the continental shelf:
A global review. Springer, New York, pp 213-232. https://doi.org/10.1007/978-1-4614-9635-9_12

Bjerck HB (2008) Norwegian Mesolithic trends: a review. In: Bailey G, Spikins P (eds) Mesolithic Europe. Cambridge University Press, Cambridge, pp 60-106

Bonsall C, Smith C (1989) Late Palaeolithic and Mesolithic bone and antler artefacts from Britain: first reaction to accelerator dates. Mesolithic Miscellany 10:33-38

Brennand M, Taylor M (2003) The survey and excavation of a Bronze Age timber circle at Holme-next-the-Sea, Norfolk, 1998-9. Proc Prehist Soc 69:1-84

Brunning R (2007) Mesolithic worked wood. In: Bell M (ed) Prehistoric coastal communities: the Mesolithic in western Britain, CBA research report 149. Council for British Archaeology, York, pp 125-130

Buglass J (1994) A Neolithic fish weir in Cleveland? Nautical Archaeology Newsletter, Autumn 4

Bynoe R, Dix JK, Sturt F (2016) Of mammoths and other monsters: historic approaches to the submerged Palaeolithic. Antiquity 90(352):857-875. https://doi. org/10.15184/aqy.2016.129

Callow P (1986) Pleistocene landscapes and the Palaeolithic economy. In: Callow P, Cornford JM (eds) La Cotte de St. Brelade 1961-1978: excavations by C.B.M. McBurney. Geo Books, Norwich, pp 365-376

Cohen KM, Westley K, Erkens G, Hijma MP, Weerts HJT (2017) The North Sea. In: Flemming NC, Harff J, Moura D, Burgess A, Bailey GN (eds) Submerged landscapes of the European continental shelf: quaternary paleoenvironments. Wiley, Chichester, pp 147-186

Coles BJ (1998) Doggerland: a speculative survey. Proc Prehist Soc 64:45-81

Dawson S, Bates R, Wickham-Jones C, Dawson A (2017) Northern North Sea and Atlantic Northwest approaches. In: Flemming NC, Harff J, Moura D, Burgess A, Bailey GN (eds) Submerged landscapes of the European continental shelf: quaternary paleoenvironments. Wiley, Chichester, pp 187-209

Eadie G, Waddington C (2013) Rescue recording of an eroding inter-tidal peat bed at Low Hauxley, Northumberland (6109). Archaeological research services report 2013/17 http://www.archaeologicalresearchservices.com/projects/Low\%20Hauxley $\% 20$ Footprints \%20\&\%20Peat\%20Deposit.pdf

Edwards R, Dix J (2012) High resolution geophysical investigation of the nearshore environment of the Wootton-Quarr coast. In: Tomalin DJ, Loader RD, Scaife RG (eds) Coastal archaeology in a dynamic environment: a Solent case study, BAR British series 568. Archaeopress, Oxford, pp 88-104

Farr RH, Momber G, Satchell J, Flemming NC (2017) Paleolandscapes of the Celtic Sea and the Channel/ La Manche. In: Flemming NC, Harff J, Moura D, Burgess A, Bailey GN (eds) Submerged landscapes of the European continental shelf: quaternary paleoenvironments. Wiley, Chichester, pp 211-239 
Fischer A (2004) Submerged Stone Age - Danish examples and North Sea potential. In: Flemming NC (ed) Submarine prehistoric archaeology of the North Sea. Research priorities and collaboration with industry, CBA research report 141. Council for British Archaeology, York, pp 23-36

Flemming NC (ed) (2004) Submarine prehistoric archaeology of the North Sea. Research priorities and collaboration with industry, CBA research report 141. Council for British Archaeology, York

Flemming NC, Harff J, Moura D, Burgess A, Bailey GN (eds) (2017) Submerged landscapes of the European continental shelf: quaternary paleoenvironments. Wiley, Chichester

Fulford M, Champion T, Long A (1997) England's coastal heritage: a survey of English Heritage and the RCHME, Archaeological report no. 15. English Heritage, London

Gaffney V, Thomson K, Fitch S (eds) (2007) Mapping Doggerland: the Mesolithic landscapes of the southern North Sea. Archaeopress, Oxford

Gaffney V, Fitch S, Smith D (eds) (2009) Europe's Lost World: the rediscovery of Doggerland, CBA research report 160. Council for British Archaeology, York

Gaffney V, Allaby R, Bates R, Bates M, Ch'ng E, Fitch S, Garwood P, Momber G, Murgatroyd P, Pallen M, Ramsey E, Smith D, Smith O (2017) Doggerland and the Lost Frontiers Project (2015-2020). In: Bailey GN, Harff J, Sakellariou D (eds) Under the sea: archaeology and palaeolandscapes of the continental shelf. Springer, Cham, pp 305-319

Godwin H, Godwin M (1933) British Maglemose harpoon sites. Antiquity 7:36-48

Godwin H, Willis EH (1959) Cambridge University natural radiocarbon measurements I. Am J Sci Radiocarbon Supplement 1:63-75

Hale A (2004) Scottish marine crannogs, British archaeological reports British series 369. Archaeopress, Oxford

Hall K (2014) Locating potential Mesolithic fish sites in Britain using predictive modelling: applying the 'fishing site model' to British conditions. In: Foulds FWF, Drinkall HC, Perri AR, Clinnick DTG, Walker JWP (eds) Wild things: recent advances in Palaeolithic and Mesolithic research. Oxbow, Oxford, pp 278-291

Hardy K, Wickham-Jones C (2009) Mesolithic and later sites around the Inner Sound, Scotland: Scotland's First Settlers project 1998-2004. Scottish Archaeology Internet Report 31

Harff J, Flemming NC, Groh A, Hünicke B, Lericolais G, Mesched M, Rosentau A, Sakellariou D, Uścinowicz S, Zhang W, Zorita E (2017) Sea level and climate. In: Flemming NC, Harff J, Moura D, Burgess A, Bailey GN (eds) Submerged landscapes of the European continental shelf: quaternary paleoenvironments. Wiley, Chichester, pp 21-49

Hazell ZJ (2008) Offshore and intertidal peat deposits, England - a resource assessment and development of a database. Environ Archaeol 13(2):101-110
Hedges REM, Housley RA, Law IA, Bronk CR (1990) Radiocarbon dates from the Oxford AMS system: archaeometry datelist 10. Archaeometry 32(1):101-108

Huddart D, Roberts G, Gonzalez S (1999) Holocene human and animal footprints and their relationship with coastal environmental change, Formby Point, NW England. Quat Int 55:29-41

Jacobi RM, Higham TFG (2008) The 'Red Lady' ages gracefully: new ultrafiltration AMS determinations from Paviland. J Hum Evol 55(5):898-907

Jacobsson P, Hale A, Hamilton D, Cook G (2017) Radiocarbon wiggle-match dating in the intertidal zone. J Island Coast Archaeol. https://doi.org/10.108 0/15564894.2017.1383323

Lambeck K (1995) Late Devensian and Holocene shorelines of the British Isles and North Sea from models of glacio-hydro-isostatic rebound. J Geol Soc Lond $152: 437-448$

Leary J (2015) The remembered land: surviving sea-level rise after the Last Ice Age. Bloomsbury, London

Long D, Wickham-Jones CR, Ruckley NA (1986) A flint artefact from the northern North Sea. In: Roe DA (ed) Studies in the Upper Palaeolithic of Britain and Northwest Europe, British archaeological reports international series 296. B. A. R, Oxford, pp 55-62

Mellars PA (1970) An antler harpoon-head of 'Obanian' affinities from Whitburn, County Durham. Archaeologia Aeliana 4th Series 48:337-346

Mellars PA (1987) Excavations on Oronsay: prehistoric human ecology on a small island. Edinburgh University Press, Edinburgh

Mithen S, Wicks K, Pine A, Riede F, Lane C, Banerjea R, Cullen V, Gittins M, Pankhurst N (2015) A Lateglacial archaeological site in the far north-west of Europe at Rbha Port an t-Seilich, Isle of Islay, western Scotland: Ahrensburgian-style artefacts, absolute dating and geoarchaeology. J Quat Sci 30(5):396-416

Momber G, Peeters H (2017) Postglacial human dispersal and submerged landscapes in North-west Europe. In: Bailey GN, Harff J, Sakellariou D (eds) Under the sea: archaeology and palaeolandscapes of the continental shelf. Springer, Cham, pp 321-334

Momber G, Tomalin D, Scaife R, Satchell J, Gillespie J (eds) (2011) Mesolithic occupation at Bouldnor Cliff and the submerged prehistoric landscapes of the Solent, CBA research report 164. Council for British Archaeology, York

Murphy P (2014) The English coast: a history and a prospect. Continuum, London

Parfitt SA, Ashton NM, Lewis SG et al (2010) Early Pleistocene human occupation at the edge of the Boreal zone in Northwest Europe. Nature 466:299233. https://doi.org/10.1038/nature09117

Pope M (2003) Placing Boxgrove into its prehistoric landscape. Archaeol Int 7:13-16. https://doi.org/10.5334/ ai.0705

Ransley J, Sturt F (eds) (2013) People and the sea: a maritime archaeological research agenda for England, CBA 
research report 171. Council for British Archaeology, York

Reid C (1913) Submerged forests. Cambridge University Press, Cambridge

Richards MP (2000) Human and faunal stable isotope analyses from Goat's Hole and Foxhole Caves, Gower. In: Aldhouse-Green S (ed) Paviland Cave and the "Red Lady": a definitive report. Western Academic and Specialist Press, Bristol, pp 71-75

Roberts MB, Parfitt SA (eds) (1999) Boxgrove: A Middle Pleistocene hominid site at Eartham Quarry, Boxgrove, West Sussex. English Heritage, London

Samson AVM (2006) Offshore finds from the Bronze Age in north-western Europe: the shipwreck scenario revisited. Oxf J Archaeol 25(4):371-388

Saville A, Ballin TB (2009) Upper Palaeolithic evidence from Kilmelfort Cave, Argyll: a re-evaluation of the lithic assemblage. Proc Soc Antiqu Scotl 139:9-45

Scales R (2007) Footprint-tracks of people and animals. In: Bell $M$ (ed) Prehistoric coastal communities: the Mesolithic in Western Britain, CBA research report 149. Council for British Archaeology, York, pp 139-159

Scott K (1986) The bone assemblages of layers 3 and 6. In: Callow P, Cornford JM (eds) La Cotte de St. Brelade 1961-1978: excavations by C.B.M. McBurney. Geo Books, Norwich, pp 159-183

Scott B, Bates M, Bates R, Conneller C, Pope M, Shaw A, Smith G (2014) A new view from La Cotte de St Brelade, Jersey. Antiquity 88:13-29

Shennan I, Andrews J (eds) (2000) Holocene landocean interaction and environmental change around the North Sea. Geological Society, London. Special Publication 166

Shennan I, Bradley S, Milne G, Brooks A, Bassett S, Hamilton S (2006) Relative sea-level changes, glacial isostatic modelling and ice-sheet reconstructions from the British Isles since the Last Glacial Maximum. J Quat Sci 21:585-599

Sidell J, Haughey F (eds) (2007) Neolithic archaeology in the intertidal zone. Oxbow, Oxford

Smith O, Momber G, Bates R, Garwood P, Fitch S, Pallen M, Gaffney V, Allaby RG (2015) Sedimentary DNA from a submerged site provides evidence of wheat in the British Isles 8000 years before present. Science 347(6225):998-1001. https://doi.org/10.1126/ science. 1261278

Sturt F, Garrow D, Bradley S (2013) New models of North West European Holocene palaeogeography and inundation. J Archaeol Sci 40:3963-3976

Sturt F, Dix J, Grant MJ (2017) The history of industrylinked research in English waters: lessons for the future. In: Bailey GN, Harff J, Sakellariou D (eds) Under the sea: archaeology and palaeolandscapes of the continental shelf. Springer, Cham, pp 425-436

Taylor M (2011) Waterlogged wood. In: Momber G, Tomalin D, Scaife R, Satchell J, Gillespie J (eds) Mesolithic occupation at Bouldnor Cliff and the submerged prehistoric landscapes of the Solent, CBA research report 164. Council for British Archaeology, York, pp 84-89

Tizzard L, Baggaley PA, Firth AJ (2011) Seabed prehistory: investigating palaeolandsurfaces with Palaeolithic remains from the southern North Sea. In: Benjamin J, Bonsall C, Pickard C, Fischer A (eds) Submerged prehistory. Oxbow, Oxford, pp 65-74

Tizzard L, Bicket AR, Benjamin J, de Loecker D (2014) A Middle Palaeolithic site in the southern North Sea: investigating the archaeology and palaeogeography of Area 240. J Quat Sci 29:698-710. https://doi. org/10.1002/jqs. 2743

Tizzard L, Bicket AR, de Loecker D (2015) Seabed prehistory: investigating the palaeogeography and Early Middle Palaeolithic archaeology in the southern North Sea, Wessex archaeology report 35. Wessex Archaeology, Salisbury

Tolan-Smith C (2008) Mesolithic Britain. In: Bailey G, Spikins P (eds) Mesolithic Europe. Cambridge University Press, Cambridge, pp 132-157

Tomalin DJ, Loader RD, Scaife RG (2012) Coastal archaeology in a dynamic environment: A Solent case study, BAR British series 568. Archaeopress, Oxford

Trechmann CT (1936) Mesolithic flints from the submerged forest at West Hartlepool. Proc Prehist Soc 2(2):161-168

Van de Noort R (2004) The Humber wetlands: the archaeology of a dynamic landscape. Windgather Press, Bollington

Van de Noort R (2014) North Sea archaeologies: a maritime biography, 10,000 BC - AD 1500. Oxford University Press, Oxford

Waddington C (ed) (2007) Mesolithic settlement in the North Sea Basin: a case study from Howick, Northeast England. Oxbow, Oxford

Waddington C (2015) A case for secondary Mesolithic colonisation of Britain following rapid inundation of the North Sea Plain. In: Ashton N, Harris C (eds) No stone unturned: papers in honour of Roger Jacobi, Lithic studies occasional paper, vol 9. Lithic Studies Society, London, pp 221-232

Warren SH, Piggott S, Clark JGD, Burkitt MC, Godwin $\mathrm{H}$, Godwin ME (1936) Archaeology of the submerged land-surface of the Essex Coast. Proc Prehist Soc 2:178-210

Waugham M, Davidson M, Innes J, Tooley M (2005) Archaeology and environment of submerged landscapes in Hartlepool Bay, England, Tees archaeology monograph series, vol 2. Tees Archaeology, Hartlepool

Wessex Archaeology (2007) Artefacts from the sea. Archaeology Data Service, York. https://doi. org/10.5284/1000260. Accessed July 2014

Westley K (2017) The northern shelf. In: Flemming NC, Harff J, Moura D, Burgess A, Bailey GN (eds) Submerged landscapes of the European continental shelf: quaternary paleoenvironments. Wiley, Chichester, pp 135-145 
Wilkinson TJ, Murphy P (1986) Archaeological survey of an intertidal zone: The submerged landscape of the Essex coast, England. J Field Archaeol 13(2):177-194

Wilkinson TJ, Murphy PL (1995) The archaeology of the Essex coast, vol. 1: The Hullbridge survey. East Anglian archaeology 71
Williams AN, Ulm S, Sapienza T, Lewis S, Turney CSM (2018) Sea-level change and demography during the last glacial termination and early Holocene across the Australian continent. Quat Sci Rev 182:144-154

Wymer JJ, Robins PA (1994) A long blade flint industry beneath Boreal peat at Titchwell, Norfolk. Norfolk Archaeol 42:13-37

Open Access This chapter is licensed under the terms of the Creative Commons Attribution 4.0 International License (http://creativecommons.org/licenses/by/4.0/), which permits use, sharing, adaptation, distribution and reproduction in any medium or format, as long as you give appropriate credit to the original author(s) and the source, provide a link to the Creative Commons licence and indicate if changes were made.

The images or other third party material in this chapter are included in the chapter's Creative Commons licence, unless indicated otherwise in a credit line to the material. If material is not included in the chapter's Creative Commons licence and your intended use is not permitted by statutory regulation or exceeds the permitted use, you will need to obtain permission directly from the copyright holder. 